San Jose State University

SJSU ScholarWorks

Master's Theses

Master's Theses and Graduate Research

1994

\title{
Genetic and biochemical characterization of bacteriophages harbored by Bacillus thuringiensis subspecies kurstaki
}

Lynn Ann Anderson

San Jose State University

Follow this and additional works at: https://scholarworks.sjsu.edu/etd_theses

\section{Recommended Citation}

Anderson, Lynn Ann, "Genetic and biochemical characterization of bacteriophages harbored by Bacillus thuringiensis subspecies kurstaki" (1994). Master's Theses. 890.

DOI: https://doi.org/10.31979/etd.xukz-tjv4

https://scholarworks.sjsu.edu/etd_theses/890

This Thesis is brought to you for free and open access by the Master's Theses and Graduate Research at SJSU ScholarWorks. It has been accepted for inclusion in Master's Theses by an authorized administrator of SJSU ScholarWorks. For more information, please contact scholarworks@sjsu.edu. 


\section{INFORMATION TO USERS}

This manuscript has been reproduced from the microfilm master. UMI films the text directly from the original or copy submitted. Thus, some thesis and dissertation copies are in typewriter face, while others may be from any type of computer printer.

The quality of this reproduction is dependent upon the quality of the copy submitted. Broken or indistinct print, colored or poor quality illustrations and photographs, print bleedthrough, substandard margins, and improper alignment can adversely affect reproduction.

In the unlikely. event that the author did not send UMI a complete manuscript and there are missing pages, these will be noted. Also, if unauthorized copyright material had to be removed, a note will indicate the deletion.

Oversize materials (e.g., maps, drawings, charts) are reproduced by sectioning the original, beginning at the upper left-hand corner and contiming from left to right in equal sections with swall overlaps. Each original is also photographed in one exposure and is included in reduced form at the back of the book

Photographs included in the original manuscript have been reproduced xerographically in this copy. Higher quality $6^{\prime \prime} \times 9^{n}$ black and white photographic prints are available for any photographs or illustrations appearing in this copy for an additional charge. Contact UMI directly to order.

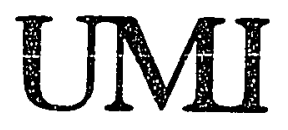





\title{
GENETIC AND BIOCHEMICAL CHARACTERIZATION OF BACTERIOPHAGES HARBORED BY BACILLUS THURINGIENSIS SUBSPECIES KURSTAKI
}

\author{
A Thesis \\ Presented to \\ the Faculty of the Department of Biological Sciences \\ San Jose State University
}

In Partial Fulfillment

of the Requirements of the Degree

Miaster of Science

by

Lynn Ann Anderson

December, 1994 
UMI Number: 1361148

UMI Microform Edition 1361148

Copyright 1995, by UMI Company. All rights reserved.

This microform edition is protected against unauthorized copying under Title 17, United States Code.

\section{UMI}

300 North Zeeb Road

Ann Arbor, MI 48103 
Lynn Ann Ariterson

ALL RIGHTS RESERVED 
APPROVED FOR THE DEPARTMENT OF BIOLOGICAL SCIENCES

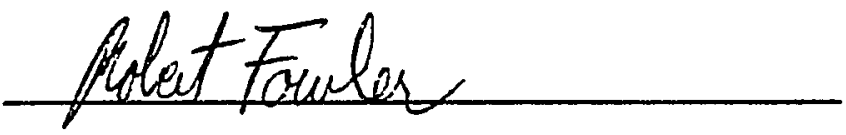

Dr. Robert Fowler

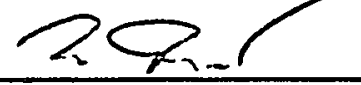

Dr. Jean_Christophe Piot

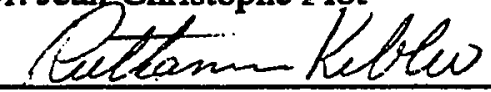

Dr. Ruth Ann Kibler

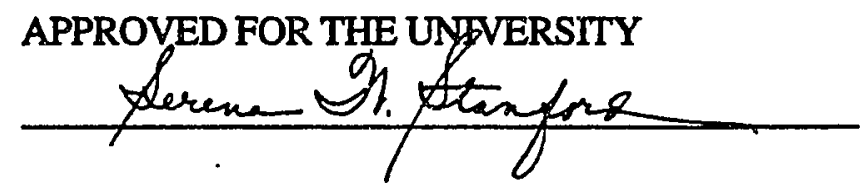




\begin{abstract}
GENETIC AND BIOCHEMICAL CHARACTERIZATION OF BACTERIOPHAGES HARBORED BY BACILLUS THURINGIENSIS SUBSPECIES KURSTAKI
\end{abstract}

\author{
by Lynn Ann Anderson
}

\begin{abstract}
Bacillus thuringiensis is used against specific crop pests and a few products containing this bacterium are manufactured by various companies. In at least some strains bacteriophage or bacteriocin-related problems such as spontaneous lysis have been observed. These problems are of significant importance in industrial scale fermentation and have prompted a study of the bacteriophages.

Four unique bacteriophages were isolated from Bacillus thuringiensis subspecies kurstaki HD119 and HD942. The phages could be distinguished by their plaque and particle morphologies, restriction endonuclease cleavage products, host range specificities and plating efficiencies on various strains of Bacillus thuringiensis. The apparent molecular sizes of the bacteriophage DNAs ranged from 29.4 to $38.3 \mathrm{~kb}$. Each of the four bacteriophages formed a stable lysogenic relationship with Bacillus cereus 569.
\end{abstract}




\section{Acknowledgements}

This thesis is dedicated to my husband, John, who encouraged me all the way, and had more faith in me than I did. To my parents, the reason I value education so much. To Christophe Piot for making the research and writing of the thesis a very rewarding and educational experience.

Thank you to my advisors Bob Fowler and Ruthann Kibler, for their input. And to Sue Kalman for her willingness to step.in and help at a crucial time in the process of writing the thesis manuscript. 


\section{Table of Contents}

Page

Abstract $\ldots \ldots \ldots \ldots \ldots \ldots \ldots \ldots \ldots \ldots \ldots \ldots \ldots \ldots \ldots$ iv

Acknowledgements $\ldots \ldots \ldots \ldots \ldots \ldots \ldots \ldots \ldots \ldots \ldots \ldots$

Table of Contents . . . . . . . . . . . . . . . . . . . . . vi

List of Tables. ............................

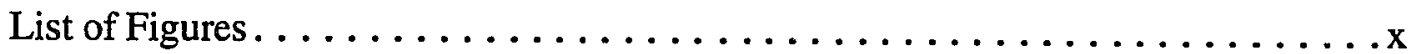

Introduction $\ldots \ldots \ldots \ldots \ldots \ldots \ldots \ldots \ldots \ldots \ldots \ldots \ldots \ldots \ldots \ldots$

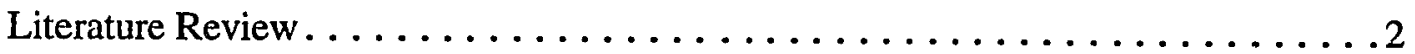

Materials and Methods. . . . . . . . . . . . . . . . . .

Bacterial strains $\ldots \ldots \ldots \ldots \ldots \ldots \ldots \ldots \ldots \ldots \ldots$

Media and growth conditions $\ldots \ldots \ldots \ldots \ldots \ldots \ldots$

DNA and protein manipulations $\ldots \ldots \ldots \ldots \ldots \ldots$

Bacteriophage induction in wild-type strains . . . . . . . . . . . 9

Purification of various bacteriophages from induced B.thuringiensis $\mathrm{HD} 119$ and

HD942 strains . . . . . . . . . . . . . . . . 10

Lysogenization of $B$. cereus 569 by $B$. thuringiensis bacteriophages . . . . . 10

Preparation of high-titer bacteriophage stocks . . . . . . . . . . . 11

Purification of bacteriophages . . . . . . . . . . . . . . . 12

Isolation of bacteriophage DNA $\ldots \ldots \ldots \ldots \ldots \ldots$

Determination of host range and plating efficiency $\ldots \ldots \ldots \ldots \ldots$

Polymerase chain reaction probe preparation $\ldots \ldots \ldots \ldots \ldots \ldots$

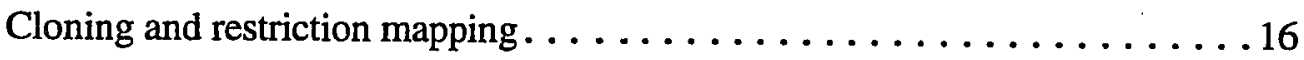


Bacteriophage protein analysis. . . . . . . . . . . . . . . 19

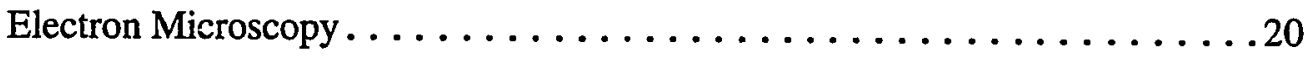

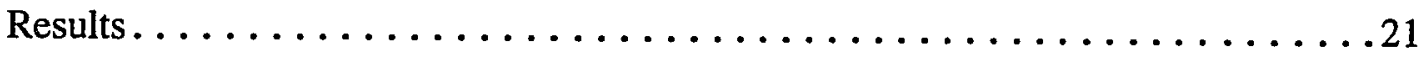

Isolation of various bacteriophages from two strains of B.thuringiensis

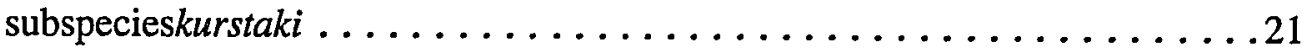

Optimization of induction parameters. . . . . . . . . . . 22

Isolation of several types of bacteriophages with distinct plaques. . . . .27

Lysogenization of $B$. cereus $569 \ldots \ldots \ldots \ldots \ldots \ldots \ldots \ldots 28$

Phage typing (cross spotting) $\ldots \ldots \ldots \ldots \ldots \ldots \ldots \ldots \ldots \ldots$

Biochemical and genetic characterization of bacteriophages isolated

from B. thuringiensis subspecies kurstaki HD119 and HD942 . . . . . . . 39

Large scale purification of $\varnothing 6-1, \varnothing 6-2, \varnothing 6-5.1$ and $\varnothing 12-1 \ldots \ldots \ldots 39$

Cesium chloride gradient purification of bacteriophage stocks. . . . . 42

Morphological characterization of the bacteriophages. . . . . . . . 44

Biochemical characterization of the bacteriophages..........46

Analysis of bacteriophage DNA .................48

Restriction site mapping of bacteriophage $\varnothing 6-2 \ldots \ldots \ldots \ldots \ldots 51$

Genetic evidence of the similarity of $\varnothing 6$-2-like bacteriophages. . . . . 52

Determination of the host range of the various bacteriophages........54

Determination of the efficiency of plating (eop) on various indicator strains . . .55

Detection of the bacteriophage $\emptyset 6-2$ by polymerase chain reaction . . . . . .59

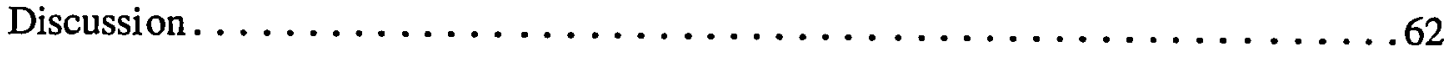

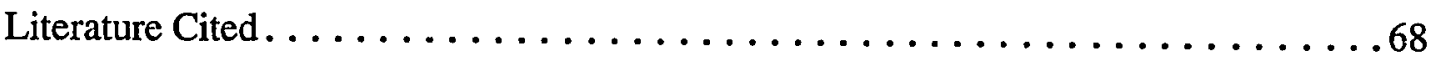




\section{List of Tables}

Table

Page

1. Bacteriophage yields following induction with ultraviolet irradiation or mitomycin $\mathrm{C}$

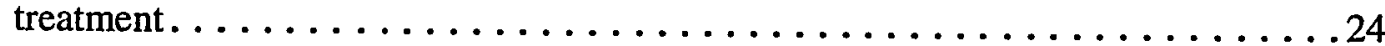

2. Plaque types obtained from $B$. thuringiensis HD119 and HD942 induced cultures . 27

3. Phage titers obtained with various mitomycin $\mathrm{C}$ concentrations on

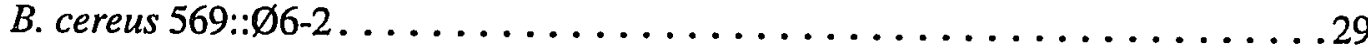

4. Bacteriophage titers obtained after induction of $B$. cereus 569 lysogens with

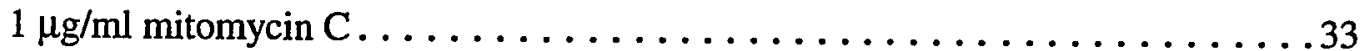

5. Yields of bacteriophage obtained from cultures infected with $\emptyset 6-5.1$ at various multiplicity of infections . . . . . . . . . . . . . . . . 35

6. Bacteriophage $\varnothing 6-5.1$ and $\varnothing 12-1$ titers obtained after induction of $B$. cereus 569 lysogens with $1 \mu \mathrm{g} / \mathrm{ml}$ mitomycin $\mathrm{C} \ldots \ldots \ldots \ldots \ldots \ldots \ldots \ldots \ldots$

7. Phage typing (cross-spotting) . . . . . . . . . . . . . . 38

8. Phage titers obtained from $500-\mathrm{ml}$ cultures of $B$. cereus 569 lysogens induced with $1 \mu \mathrm{g} / \mathrm{ml}$ mitomycin $\mathrm{C} \ldots \ldots \ldots \ldots \ldots \ldots \ldots \ldots \ldots \ldots$

9. Phage titers obtained after induction of B. cereus 569 lysogens grown in $100 \mathrm{ml}$ cultures $\ldots \ldots \ldots \ldots \ldots \ldots \ldots \ldots \ldots \ldots \ldots \ldots \ldots \ldots \ldots \ldots \ldots$

10. Recovery of bacteriophage applied to cesium chloride gradients . . . . . . .44

11. Dimensions of bacteriophage particles $\ldots \ldots \ldots \ldots \ldots \ldots \ldots$

12. Apparent molecular weight of phage proteins $\ldots \ldots \ldots \ldots \ldots \ldots \ldots$ 
13. Determination of the presence of restriction endonuclease sites on bacteriophage DNA. ........................ 50

14. Sizes of $E c o R I$ restriction fragments and deduced total genome sizes of $D$. thuringiensis bacteriophages $\ldots \ldots \ldots \ldots \ldots \ldots \ldots \ldots \ldots \ldots \ldots \ldots \ldots \ldots$

15. Host ranges of four bacteriophages . . . . . . . . . . . . . 55

16. Titers of plating bacteriophages $\varnothing 6-1, \varnothing 6-2, \varnothing 6-5.1$ and $\varnothing 12-1$ on various $B$. thuringiensis isolates and $B$. cereus $569 \ldots \ldots \ldots \ldots$

17. Efficiency of plating bacteriophages $\varnothing 6-1, \varnothing 6-2, \varnothing 6-5.1$ and $\emptyset 12-1$ on various $B$. thuringiensis isolates and $B$. cereus $569 \ldots \ldots \ldots \ldots 7$

18. Influence of the host strain on the efficiency of plating of bacteriophages

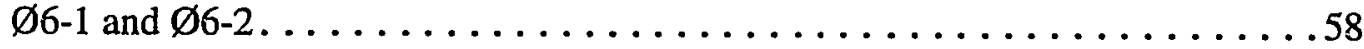

19. Oligonucleotide primers for the detection of $\varnothing 6-2 \ldots \ldots \ldots \ldots \ldots \ldots$

20. Amplification of fragments of bacteriophage DNA by PCR $\ldots \ldots \ldots \ldots \ldots$ 


\section{List of Figures}

$\begin{array}{lll}\text { Figure Page } & \text { Pag }\end{array}$

1. Lysis of culture growth of $B$. thuringiensis subspecies kurstaki HD119 . . . . . 21

2. Induction of HD942 through ultraviolet irradiation or incubation with mitomycin

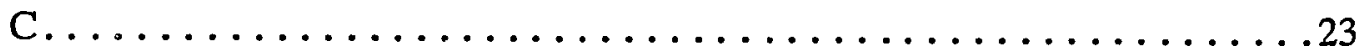

3. HD942 induction with ultraviolet irradiation for 25 seconds or mitomycin C

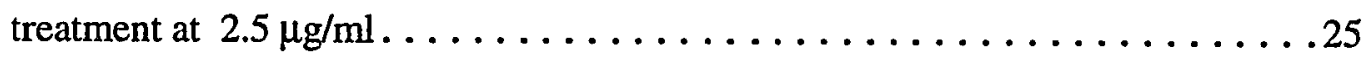

4. HD119 induced with ultraviolet 25 seconds, mitomycin C $2.5 \mu \mathrm{g} / \mathrm{ml} \ldots \ldots \ldots 26$

5. B. cereus 569 lysogens $6-1,6-2,6-3$ and 6-5.3 induced with $1 \mu \mathrm{g} / \mathrm{ml} \mathrm{mitomycin}$

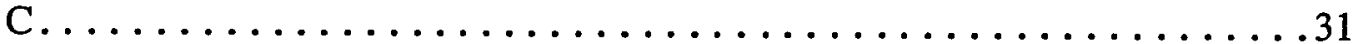

6. B. cereus 569 lysogens $12-2,12-3$ and $12-7$ induced with $1 \mu \mathrm{g} / \mathrm{ml}$ mitomycin C. . 32

7. $\mathrm{A}_{600}$ of $\emptyset 6-5.1$ at various time points, m. o. i. $0.1,0.01$ and $1 \ldots \ldots \ldots 34$

8. B. cereus 569 lysogens of bacteriophage $\emptyset 6-5.1$ and $\emptyset 12-1$ induced

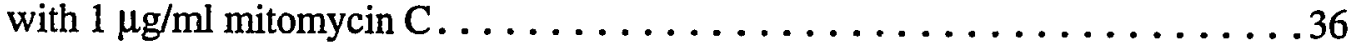

9. Induction of $B$. cereus 569 lysogens, $500 \mathrm{ml}$ cultures . . . . . . . . . . . . . . . 40

10. Cesium chloride gradients of concentrated bacteriophage stocks . . . . . . 43

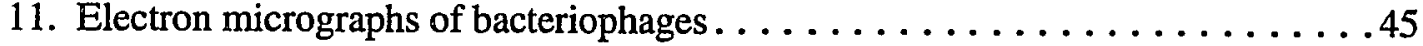

12. SDS-PAGE gels of bacteriophage structural proteins . . . . . . . . . . 47

13. Agarose gel electrophoresis of bacteriophage DNA digested with Sau3AI restriction endonuclease. . . . . . . . . . . . . . . . . . . . 499

14. Physical map of bacteriophage $\emptyset 6-2$ for restriction endonucleases

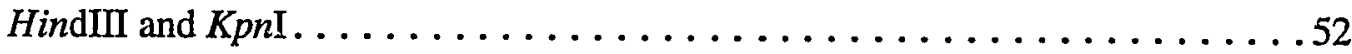

15. Restriction patterns of bacteriophages belonging to the $\emptyset 6-2$ family . . . . . . 53 


\section{Introduction}

Bacillus thuringiensis (B. thuringiensis) is a gram positive, sporulating bacterium characterized by its ability to synthesize a variety of insecticidal proteins during sporulation. These proteins are produced at very high levels, and form cytoplasmic inclusions, often in the form of crystalline structures. $B$. thuringiensis can be used against specific crop pests and a number of commercial products containing this bacterium are manufactured by various companies.

In order to improve the insecticidal activity of $B$. thuringiensis strains, researchers have developed transgenic derivatives of the strains used in commercial products (Thorne, 1978; Perlak et al., 1979; Gamel and Piot, 1992). In at least some of these strains bacteriophage- or bacteriocin-related problems such as spontaneous lysis have been observed. These problems are of significant importance in industrial scale fermentation and have prompted me to initiate a study of the bacteriophages harbored by $B$. thuringiensis strains used in the production of biological insecticides.

During my investigation four unique bacteriophages were isolated from $B$. thuringiensis subspecies kurstaki strains HD1 19 and HD942, whose characteristics are described in this thesis. The phages were distinguished on the basis of their plaque and particle morphologies, location of restriction endonuclease cleavage sites, electrophoresis patterns of their structural proteins, and host range specificities as well as plating efficiencies. 


\section{Literature Review}

Most of the quite limited literature found on $B$. thuringiensis bacteriophages deals with either the physiological characterization of bacteriophages isolated after induction with genotoxic agents (Auffray and Poutibonnes, 1985; Inal et al., 1990; Kochkina et al., 1978; Rautenshtein et al.,1970; Reynolds et al., 1988), or with generalized transduction promoted by bacteriophages isolated from Bacillus cereus or B. thuringiensis (Inal et al., 1992; Landén et al., 1981; Lecadet et al., 1980; Thorne, 1978).

In general, bacteriophage are currently classified into 12 families. Tailed phages, all of which contain double-stranded (ds) DNA, constitute $95 \%$ of bacteriophages, and fall into three families defined by tail structure. Myoviridae are phage with contractile tails, Siphoviridae have long, noncontractile tails, and Podoviridae have short tails (Francki et al., 1991). When Bacillus phages were first classified in 1974, there were 12 species of tailed phages defined by their morphology and the physiochemical properties of the phage particles and their DNA (Ackermann, 1974). More recently, nine new species of Bacillus bacteriophage were described, which were novel, based on their morphological and physiochemical properties (Ackermann et al., 1994).

Temperate bacteriophages from $B$. thuringiensis subspecies galleriae obtained upon induction with ultraviolet light, hydrogen peroxide and mitomycin $\mathrm{C}$ were characterized (Colasito and Rogoff, 1969). In this study, the particle morphology as well as the host ranges of eight bacteriophages were described. Bacteriophages with similar morphology were found to have the same host range. In another study (Kochkina et al., 1978) a polylysogenic strain of $B$. thuringiensis subspecies galleriae was examined. It was noted that phage-induced lysis was frequently observed in cultures of this subspecies, which is 
widely used in a number of countries for the production of insecticides, and in this case, the lysis was caused by virulent mutants of the temperate phage harbored by this strain. A further study (Kochkina, 1986a) examined the peculiarities between the two phages that were isolated from this culture. The phage differ in particle morphology, but exhibit a cross-reactivity in immunoassay using antiphage sera, and thus appear to be antigenically related. A further study evaluated structural features of the two phages (Kochkina, 1986b). The spectral properties of DNA isolated from the two phages was evaluated. Results point to a double stranded, helical structure of the DNA. The DNAs differ in their sequence, as shown by the molar content of the nitrogenous bases and in the character of their distribution along the molecule.

In a study by Azizbekyan et al. (1980), various strains of $B$. thuringiensis were analyzed for phages, and all of the cultures examined were shown to be able to release phages. The subspecies of $B$. thuringiensis included in this study were galleriae, dendrolimus, tolworthi and insectus. B. thuringiensis insectus was found to be lysogenic. The phages it released were of an unusual morphology for $B$. thuringiensis phages; they had hexagonal heads and no tails. Reynolds et al. (1988) isolated five temperate phages from a polylysogenic strain of $B$. thuringiensis subspecies aizawai. These could be distinguished by their host ranges, plaque and particle morphologies, serological specifications, and locations of restriction endonuclease cleavage sites on their chromosomes. The phages all maintain a stable lysogenic relationship with $B$. cereus. Kanda and Aizawa (1988) described the selective induction of two temperate bacteriophages from $B$. thuringiensis strain AF101 with ethidium bromide and ultraviolet irradiation. Botk phage are inducible by either agent. The host range of the two phages are identical and include $B$. thuringiensis subspecies sotto and israelensis, which show a lytic 
response to the phages. Comparison of DNA restriction patterns of their genomes show that they differ. In a study of five bacteriophages of the Myoviridae family, Jarvis et al. (1993) shows that these phages are morphologically identical and have similar protein patterns, yet differ considerably in their burst size. Their genomes, which are 95 to 166 kilobases $(\mathrm{kb})$ in size, are shown to be distinct by DNA-DNA hybridization and restriction endonuclease analysis.

Transmission electron microscopy has been a valuable tool in the characterization of $B$. thuringiensis bacteriophages. One study investigated the fine structures of tailed phages from $B$. thuringiensis subspecies galleriae (Rautenshtein et al., 1975). The study revealed the presence, on the tail, of a collar-like structure with teeth-like appendages. Phages of similar morphology were found in many strains of $B$. thuringiensis subspecies galleriae. Smirnova et al. (1979) examined the interaction between various morphologically distinct phages and $\mathrm{R}$ and $\mathrm{S}$ variants of $B$. thuringiensis subspecies galleriae. The morphological diversity of $B$. thuringiensis phages suggests a multiplicity of adsorption mechanisms and the presence of several types of receptors. A microscopic study of the intracellular development of a phage specific for $B$. thuringiensis subspecies galleriae showed the successive stages of phage development, from the absorption of phage particles to the cell wall, to the release of the phage from the cell. The phage adsorbs to the cell wall at the level of the enlarged tip of the tail. The prongs of the "collar," which is located near the head, appears to contact the surface of the bacterial cell wall upon adsorption and to release lytic enzymes. The burst size of the phage studied varied from several hundred to over one thousand particles per cell.

Phages from industrial cultures of $B$. thuringiensis strains that had spontaneously lysed have been examined in several studies. A biological and physiochemical analysis of 
phages isolated from a failed production batch of strain H1-98 was conducted by Koroleva et al. (1990). Two morphologically distinct groups of phage were found. One of the phage had a high burst size, a dangerous feature for industrial production. Restriction analysis did not reveal any difference in the genetic makeup between the two morphological groups of phages. Bacterial mutants resistant to these phages were obtained; however, the authors advise against the use of these mutant $B$. thuringiensis strains because of the occurrence of modified phages with a broadened host range. Besaeva et al. (1987) presents data on the effect of cultivation conditions on the intensity of spontaneous phage induction, which was shown to take place during the germination stage of the thermoactive spores. Subsequent lytic cycles occur during active growth of the cultures, but the increase in phage titer stops before the end of the vegetative growth phase. Forced aeration was also another factor causing the appearance of bacteriophages (Zamola et al., 1983).

Phages naturally associated with $B$. thuringiensis subspecies aizawai were shown to be relevant to strain identification (Jones et al., 1983): Sixteen out of thirty-six $B$. thuringiensis subspecies aizawai strains studied were naturally associated with bacteriophages. Host range, along with plaque morphology and differences in cold lability, were used to taxonomically differentiate between strains of this subspecies.

Bacteriophage-resistant mutants of $B$. thuringiensis have been isolated by several groups. In one study, the phage-resistent $B$. thuringiensis shows decreased virulence, resistance to seven phages and the loss of flagella (Heierson et al., 1986). However, decreased virulence was not coupled to phage resistance or the lack of a flagella because other mutants affected in these properties are virulent. Koroleva et al. (1992) isolated and characterized thirty-four phage-resistant mutants of $B$. thuringiensis strain H1-177-131. 
The development of phages is limited to various degrees in the phage-resistant mutants, which retain normal levels of endotoxin synthesis and spore titers. Resistance is not due to a modification of the phage recentors, but rather to changes in the mechanisms of intracellular development.

In this study data will be presented on the genetic and biochemical characterization of bacteriophages from the two strains of $B$. thuringiensis subspecies kurstaki. A better understanding of the biology of the phages harbored by this economically important microorganism will hopefully lead to the development of more reliable strains for the largescale production of biological insecticides. 


\section{Materials and Methods}

\section{Bacterial strains}

All Bacillus thuringiensis (B. thuringiensis) strains were obtained from C. Y. Chen, Sandoz Agro. The strains labelled HD originated from the culture collection of Howard Dulmage. Bacillus cereus NRRL 569 (Agricultural Research Service, Northern Regional Research Laboratory, U. S. Department of Agriculture, Peoria, Ill.) was a gift from Curtis Thorne. Escherichia coli DH5 $\alpha$ (Gibco BRL) was used as a host in cloning experiments.

\section{Media and growth conditions}

B. thuringiensis, B. cereus and $E$. coli strains were grown in Luria-Bertani (LB) (per liter: Bacto Tryptone (Difco), 10 g; Bacto Yeast Extract (Difco), 5 g; NaCl, 5 g; pH 7.0), unless otherwise stated. For phage assays, PA medium (per liter: Bacto Nutrient broth, $8 \mathrm{~g} ; \mathrm{NaCl}, 5 \mathrm{~g} ; \mathrm{MgSO}_{4} \cdot 7 \mathrm{H}_{2} 0,0.05 \mathrm{~g} ; \mathrm{MnSO}_{4} \cdot \mathrm{H}_{2} 0,0.2 \mathrm{~g} ; \mathrm{CaCl}_{2} \cdot 2 \mathrm{H}_{2} 0,0.05 \mathrm{~g} ; \mathrm{pH}$ 6.0), was used throughout. PA agar and PA soft agar contained $15 \mathrm{~g}$ and $5 \mathrm{~g}$ Bacto agar per liter respectively. CYS medium (per liter: Casitone (Difco), $10 \mathrm{~g}$; glucose, $5 \mathrm{~g}$; Bacto Yeast Extract (Difco), $2 \mathrm{~g} ; \mathrm{KH}_{2} \mathrm{PO}_{4}, 1 \mathrm{~g} ; \mathrm{MgCl}_{2,}, 500 \mathrm{mM} ; \mathrm{MnCl}_{2}, 50 \mathrm{mM} ; \mathrm{ZnSO}_{4}, 50$ $\mathrm{mM} ; \mathrm{FeCl}_{2}, 50 \mathrm{mM} ; \mathrm{CaCl}_{2}, 200 \mathrm{mM}$ ) was used in the preparation of $B$. thuringiensis and B. cereus 569 spore stocks. SOC medium (per liter: Bacto Tryptone (Difco), 20 g; Bacto Yeast Extract (Difco ), $5 \mathrm{~g} ; \mathrm{NaCl}, 0.6 \mathrm{~g} ; \mathrm{KCl}, 0.5 \mathrm{~g} ; \mathrm{MgCl}_{2}, 10 \mathrm{mM}$; glucose, $20 \mathrm{mM}$; pH 7.0) was used for the recovery of $E$. coli after transformation. Where needed ampicillin (Amp), 5-bromo-4-chloro-3-indolyl- $B-D$-galactoside (X-Gal), isopropyl- $B$-D-thiogalacto- 
pyranoside (IPTG) were added to a final concentration of $75 \mu \mathrm{g} / \mathrm{ml}, 60 \mu \mathrm{g} / \mathrm{ml}, 1 \mathrm{mM}$ respectively. Purified bacteriophage stocks were stored in SM buffer (per liter: $\mathrm{NaCl}, 5.8$ g; $\mathrm{MgSO}_{4} \cdot 7 \mathrm{H}_{2} \mathrm{O}, 2 \mathrm{~g}$; Tris.HCl, $50 \mathrm{mM}$; Gelatin, $0.1 \mathrm{~g} ; \mathrm{pH} 7.5$ ). Unless otherwise stated, the liquid cultures were grown at $30^{\circ} \mathrm{C}$ in a shaking incubator running at $300 \mathrm{rpm}$.

\section{DNA and protein manipulations}

Restriction enzymes were obtained from Pharmacia Biotech or New England Biolabs and used under the conditions described by the manufacturer. DNA was stored in TE buffer (Tris·HCl, $10 \mathrm{mM}$; EDTA, $1 \mathrm{mM}$; pH 8.0) or sterile NANOpure (Barnstead) water. Oligonucleotides were synthesized on a PCR-Mate synthesizer (Applied Biosystem, 391 DNA Synthesizer). PCR reactions were performed with AmpliTaq (Perkin-Elmer) in PCR buffer (Tris- $\mathrm{HCl}, 10 \mathrm{mM} ; \mathrm{KCl}, 50 \mathrm{mM} ; \mathrm{MgCl}_{2}, 1.5 \mathrm{mM}$; deoxyribonucleoside triphosphates (dNTPs), $200 \mu \mathrm{M}$; gelatin, 0.1\% (wt/vol); pH 8.3). Primer concentration was $1 \mu \mathrm{M}$. The reactions were run for $20-25$ cycles $\left(94^{\circ} \mathrm{C}, 0.25\right.$ minutes; $52^{\circ} \mathrm{C}, 0.5$ minutes; $72^{\circ} \mathrm{C}, 1$ minute) in a Perkin-Elmer Thermal Cycler (GeneAmp 9600), using 0.2 ml PCR microtubes (StripEase, Robbins Scientific). DNA was analyzed by agarose gel electrophoresis run in TBE buffer (per liter: Tris-borate, $89 \mathrm{mM}$; EDTA, $2.5 \mathrm{mM}$; pH 8.3). Preparative agarose gels were run in TAE buffer (per liter: Tris-base, 40 mM; EDTA, 1 $\mathrm{mM}$; sodium acetate, $5 \mathrm{mM}$; $\mathrm{pH} 7.6$ ).

Proteins were analyzed by SDS-PAGE, performed according to the method of Laemmli (1970). Proteins were denatured by boiling for 5 minutes in SDS-PAGE loading buffer (63 mM Tris $\mathrm{HCl}$ (pH 6.8), $10 \%$ glycerol, $2 \%$ SDS, $0.05 \%$ bromophenol blue, $5 \%$ 2-Mercaptoethanol) and were analyzed on an 8-16\% Tris-Glycine gradient gels, in a discontinuous system. 


\section{Bacteriophage induction in wild-type strains}

B. thuringiensis HD119 and HD942 were grown on LB agar overnight at $30^{\circ} \mathrm{C}$. A single colony was used to inoculate $10 \mathrm{ml} \mathrm{LB}$ in a $125-\mathrm{ml}$ shake flask. The culture was grown to an absorbance at $600 \mathrm{~nm}\left(\mathrm{~A}_{600}\right)$ of 0.2 , and then induced by ultraviolet (UV) irradiation or treatment with mitomycin C (Sigma), according to the method of Inal et al. (1990).

For UV induction, the culture was centrifuged $\left(10,000 \mathrm{rpm}, 1\right.$ minute, $\left.20^{\circ} \mathrm{C}\right)$ and the pellet was resuspended in $10 \mathrm{ml}$ of $\mathrm{MgSO}_{4}(10 \mathrm{mM} ; \mathrm{pH} 7.0)$. The $10-\mathrm{ml}$ suspension was placed in a 5-cm (diameter) open petri dish and swirled gently under a sterilizing UV light placed at a distance of $73 \mathrm{~cm}$ for a period of time ranging from 25 to 100 seconds. The dose rate for UV irradiation equaled $1.3 \mathrm{~J} / \mathrm{m}^{2}$ per second. The irradiated sample was centrifuged $\left(10,000 \mathrm{rpm}, 1\right.$ minute, $\left.20^{\circ} \mathrm{C}\right)$, the pellet was resuspended in $10 \mathrm{ml}$ of LB prewarmed at $30^{\circ} \mathrm{C}$, and transferred to a foil-covered, $125-\mathrm{ml}$ shake flask. An unirradiated culture was used as a control. The $\mathrm{A}_{600}$ was measured at regular intervals, and once it had dropped below a value of 0.09 , the culture was centrifuged $(10,000 \mathrm{rpm}, 10$ minute, $20^{\circ} \mathrm{C}$ ). The supernatant, containing the phages, was filtered through a cellulose acetate filter (Whatman) with a pore size of $0.45 \mu \mathrm{m}$. The phage stocks were stored at $4^{\circ} \mathrm{C}$, over a drop of chloroform.

For mitomycin $\mathrm{C}(\mathrm{MMC})$ induction, $\mathrm{MMC}$ was added at concentrations ranging from 0.1 to $10 \mu \mathrm{g} / \mathrm{ml}$ and the culture was incubated for 15 minutes at $30^{\circ} \mathrm{C}$ in a shaking incubator running at $300 \mathrm{rpm}$. The culture was then centrifuged $(10,000 \mathrm{rpm}, 1$ minute, $20^{\circ} \mathrm{C}$ ), the cells were washed by resupending the pellet in $20 \mathrm{ml} \mathrm{LB}$, centrifuging once more as above, and resuspending the pellet in $10 \mathrm{ml}$ of $\mathrm{LB}$ pre-warmed to $30^{\circ} \mathrm{C}$. The cultures were then processed as the UV-induced cultures. A non-induced culture was used 
as a control.

\section{Purification of various bacteriophages from induced B.thuringiensis HD119 and HD942 strains}

Lysates obtained by induction of $B$. thuringiensis strains HD119 and HD942 were diluted and aliquots were mixed with $5 \mathrm{ml}$ soft PA agar containing approximately 108 spores of $B$. cereus 569 and plated on PA agar. The plates were incubated overnight at $30^{\circ} \mathrm{C}$, with the overlay on top. For each plaque type, based on plaque morphology, an agar plug was taken with a sterile Pasteur pipette and macerated in $100 \mu 11 \%$ peptone to release the bacteriophages. The suspension was then serially diluted and aliquots were plated on PA plates as described above. The various phages were purified by repeating these steps until one single type of plaque was obtained. The phages were harvested by scraping and macerating the soft PA agar overlay in $5 \mathrm{ml} \mathrm{SM}$ buffer by repeated pipetting followed by centrifugation at $6,000 \mathrm{rpm}$ for 10 minutes at $4^{\circ} \mathrm{C}$ to remove the agar and bacterial debris. The lysates were filtered and stored as described above.

\section{Lysogenization of $B$. cereus 569 by $B$. thuringiensis bacteriophages}

A PA soft agar overlay containing $1 \times 10^{8}$ spores of a phage-free $B$. cereus 569 strain was plated on a PA agar plate (Ruhfel et al., 1984). Once set, a drop of lysate containing $6 \times 10^{3}$ to $1.8 \times 10^{5} \mathrm{pfu}$ of each bacteriophage lysate was spotted on the overlay (primary plate). The plate was incubated at $30^{\circ} \mathrm{C}$ overnight. Colonies growing in the zone cleared by the bacteriophage were streaked onto LB agar plates and incubated at $30^{\circ} \mathrm{C}$ overnight in order to obtain isolated colonies. Twenty isolated colonies from each spot were individually resuspended in $100 \mu \mathrm{l}$ of $1 \%$ peptone. About $1 \mu \mathrm{l}$ of the cell suspension 
was plated on a LB plate for storage and the remainder was added to $4 \mathrm{ml}$ molten PA soft agar and plated on PA agar. Once set, the same phage lysate used to infect the primary plate was spotted on the overlay, and the plate was incubated overnight at $30^{\circ} \mathrm{C}$. The isolates that showed no clearing from the phage lysate were supposed to be either immune to superinfection due to lysogenation, or resistant to phage infection, and were further characterized. Lysogeny was tested by determining the ability of the isolates to produce phage particles upon induction by UV irradiation or treatment with MMC.

\section{Preparation of high-titer bacteriophage stocks}

One isolated colony of each $B$. cereus 569 lysogen was resuspended in $10 \mathrm{ml} \mathrm{LB}$ in a $125-\mathrm{ml}$ shake flask and incubated overnight with shaking at $300 \mathrm{rpm}$ at room temperature. After measuring the $A_{600}$ of the overnight culture, a fresh culture was prepared by inoculating $500 \mathrm{ml}$ to $2000 \mathrm{ml}$ of LB with an aliquot of the overnight culture in order to obtain a starting $A_{600}$ of 0.02 . The culture was shaken at $300 \mathrm{rpm}$ and $30^{\circ} \mathrm{C}$ until the $A_{600}$ reached a value of 0.2 , and was then induced by adding $M M C$ to a final concentration of $1 \mu \mathrm{g} / \mathrm{ml}$. After a 15 minute incubation with shaking at $300 \mathrm{rpm}$ and $30^{\circ} \mathrm{C}$, the $\mathrm{MMC}$ was removed by centrifuging the culture $\left(10,000 \mathrm{rpm}, 5\right.$ minutes, $\left.25^{\circ} \mathrm{C}\right)$, resuspending the pellet in $20 \mathrm{ml} \mathrm{LB}$ pre-warmed at $30^{\circ} \mathrm{C}$, centrifuging again as above and resuspending the pellet in the original volume of pre-warmed LB. The induced culture was then incubated in the same conditions as above, and the $A_{600}$ was measured at regular intervals. After lysis, the culture was stored at $4^{\circ} \mathrm{C}$. The titer of the phage suspensions was determined by diluting and plating aliquots of the lysates as described above.

For two of the bacteriophages, $B$. cereus 569 lysogens could not be obtained immediately. Therefore, the following alternate method for preparing high-titer stocks was 
used. An overnight culture of B. cereus 569 was diluted in $20 \mathrm{ml}$ of LB to a starting $\mathrm{A}_{600}$ of 0.02 , and grown shaking at $30^{\circ} \mathrm{C}$ until the $\mathrm{A}_{600}$ reached a value of 0.2 (approximately $\left.1 \times 10^{7} \mathrm{cfu} / \mathrm{ml}\right)$. Aliquots of the culture were mixed with the bacteriophage stocks in order to obtain a multiplicity of infection (m. o. i.) of $0,0.01,0.1$ or 1 . The mixtures were incubated at $30^{\circ} \mathrm{C}$ without shaking for 16 hours to allow bacteriophage adsorption and multiplication. To further increase the phage titer, the overnight culture was mixed with molten soft PA agar and plated on a 150-mm (diameter) PA agar plate. If the overnight culture was judged too clear, $1 \times 108$ colony-forming units (cfu) B. cereus 569 spores were added prior to plating. The plates were incubated at $30^{\circ} \mathrm{C}$ overnight. Phages were harvested from the plates by scraping off and macerating the overlay in $5 \mathrm{ml}$ of SM buffer. Bacterial debris were removed by centrifugation $\left(6,000 \mathrm{rpm}, 10\right.$ minutes, $\left.20^{\circ} \mathrm{C}\right)$ and the lysate was filtered and stored as described above.

\section{Purification of bacteriophages}

Bacteriophages were purified as described by Maniatis et al. (1985). Culture lysates were incubated with deoxyribonuclease I (DNase I) and ribonuclease A (RNase A) at $1 \mu \mathrm{g} / \mathrm{ml}$ each for 1 hour at room temperature. The phage particles were disassociated from the bacterial debris by the addition of $\mathrm{NaCl}$ to a final concentration of $1 \mathrm{M}$, followed by a 1-hour incubation on ice. The bacterial debris were removed by centrifugation $\left(10,000 \mathrm{rpm}, 10\right.$ minutes, $\left.4^{\circ} \mathrm{C}\right)$. The phage were precipitated by the addition of polyethylene glycol (PEG, molecular weight $8000 \mathrm{~g} / \mathrm{mol}$ ) to a final concentration of $10 \%$ (wt/vol) followed by a 1-hour incubation on ice. The precipitated bacteriophages were recovered by centrifugation $\left(11,000 \mathrm{rpm}, 10\right.$ minutes, $\left.4^{\circ} \mathrm{C}\right)$. The supernatant was decanted and the pellet was soaked in $4 \mathrm{ml}$ of SM buffer to allow resuspension of the bacteriophage 
particles. The concentrated phage stocks were extracted once with chloroform and further purified on discontinuous $\mathrm{CsCl}$ density gradients made of 5-ml steps of $\mathrm{CsCl}$ solutions of densities $1.3,1.4,1.5$ and $1.7 \mathrm{~g} / \mathrm{ml}$ respectively. The phage stocks were layered on top of the $\mathrm{CsCl}$ gradients and centrifuged for 2 hours at $22,000 \mathrm{rpm}(109,000 \mathrm{xg})$ at $4^{\circ} \mathrm{C}$ in a Beckman SW28 rotor. The opalescent phage bands were collected through the wall of the tube with a syringe fitted with a 18-gauge hypodermic needle. The $\mathrm{CsCl}$ was diluted either by the dropwise addition of SM buffer or by delicately overlaying the collected gradient fraction with SM buffer and allowing diffusion of the $\mathrm{CsCl}$ overnight at $4^{\circ} \mathrm{C}$. Phages were pelleted by centrifugation at $22,000 \mathrm{rpm}(109,000 \mathrm{xg})$, for 2 hours at $4^{\circ} \mathrm{C}$ in a Beckman SW28 rotor. The pellet was overlaid with $0.5 \mathrm{ml} \mathrm{SM}$ buffer and left for 16 hours at $4^{\circ} \mathrm{C}$ to allow resuspension.

\section{Isolation of bacteriophage DNA}

Bacteriophage DNA was extracted as described by Maniatis et al. (1985), as follows. To a solution containing $2 \times 10^{9}$ to $9 \times 10^{12}$ pfu contained in $500 \mu \mathrm{IM}$ in a microfuge tube, disodium ethylenediaminetetra-acetate $2 \mathrm{H}_{2} \mathrm{O}$ (EDTA), proteinase $\mathrm{K}$ and sodium dodecycl sulfate (SDS) were added to final concentrations of $20 \mathrm{mM}, 5 \mathrm{~g} / \mathrm{l}$ and $0.05 \mathrm{~g} / \mathrm{l}$ respectively. The mixture was incubated at $56^{\circ} \mathrm{C}$ for 1 hour, and cooled to room temperature. An equal volume of phenol/chloroform mixture (1/1 vol/vol) equilibrated with $50 \mathrm{mM}$ Tris ( $\mathrm{pH} \mathrm{8.0),} \mathrm{was} \mathrm{added} \mathrm{to} \mathrm{the} \mathrm{treated} \mathrm{bacteriophage} \mathrm{suspension.} \mathrm{The} \mathrm{mixture}$ was homogenized by shaking for 30 seconds on a vortex mixer and incubated at $45^{\circ} \mathrm{C}$ for 15 minutes. Phases were separated by centrifugation at $14,000 \mathrm{rpm}$ for 5 minutes, the aqueous layer was transferred to a new tube, and was extracted once with an equal volume 
of chloroform/isoamyl alcohol mixture $(24 / 1, \mathrm{vol} / \mathrm{vol})$. The phases were separated as described above, and the aqueous phase was transferred to a new tube. Sodium acetate ( $\mathrm{pH}$ 6.0) was added to a final concentration of $0.3 \mathrm{M}$, and the DNA was precipitated by the addition of 2 volumes of ice-cold $100 \%$ ethanol and pelleted by centrifugation at 14,000 rpm for 30 minutes at $4^{\circ} \mathrm{C}$ in a microfuge. The pellet was washed twice with $70 \%$ ethanol, air dried for 5 minutes, and resuspended in 50 to $100 \mu \mathrm{l}$ TE buffer.

\section{Determination of host range and plating efficiency}

Spore stocks of $B$. cereus 569 and representative strains belonging to several subspecies of $B$. thuringiensis were prepared as follows. An isolated colony of each strain was inoculated in $100 \mathrm{ml} \mathrm{CYS}$, and incubated with shaking at $300 \mathrm{rpm}, 30^{\circ} \mathrm{C}$ for 48 hours. The sporulated cultures were centrifuged $\left(6,000 \mathrm{rpm}, 10\right.$ minutes, $\left.4^{\circ} \mathrm{C}\right)$. The pellets were washed once with $20 \mathrm{ml}$ sterile distilled water, centrifuged and resuspended in $10 \mathrm{ml}$ distilled water. The spore suspensions were heat-treated for 45 minutes at $65^{\circ} \mathrm{C}$. Spore titers were determined by plating aliquots of various dilutions of the spore stocks on LB agar which were incubated overnight at $30^{\circ} \mathrm{C}$.

The plating efficiencies were determined as follows. PA agar overlays containing $1 \times 10^{8}$ spores were plated on PA agar plates. Once set, a $2 \mu 1$ aliquot of each bacteriophage suspension was spotted onto the overlay, and the plate was incubated, overnight, at $30^{\circ} \mathrm{C}$ with the overlay on top. Plating efficiency was determined by mixing aliquots of each serially diluted phage stocks with $1 \times 10^{8}$ spores of each host in $4 \mathrm{ml} \mathrm{PA}$ soft agar and plating on PA agar plates. The plates were incubated overnight as indicated above. 


\section{Polymerase chain reaction probe preparation}

Bacteriophage DNA and pUC18 plasmid vector (Pharmacia) were digested with HindIII (Gibco BRL, REact 2, 1 hour, $37^{\circ} \mathrm{C}$ ). The vector was dephosphorylated with Shrimp Alkaline Phosphatase (United States Biochemical; 1 hour, $37^{\circ} \mathrm{C}$ ). The digested, dephosphorylated vector was run on a preparative $0.8 \%$ agarose gel and the vector band was excised. The agarose was cleaved to neoagro-oligosaccharides (Yaphe, 1957) with Agarase (Boehinger Mannheim Biochemicals) as follows. The gel slice was placed in a tared tube to determine its weight, 0.04 volumes of $25 \mathrm{x}$ agarase buffer (Boehinger Mannheim Biochemicals) was added and the agarose was melted by incubating at $65^{\circ} \mathrm{C}$ for 15 minutes. The molten agarose was cooled to $45^{\circ} \mathrm{C}, 1$ unit of agarase per $100 \mathrm{mg}$ of agarose was added, and the mixture was incubated at $45^{\circ} \mathrm{C}$ for 1 hour. The agarose oligomers were precipitated by the addition of sodium acetate to a final concentration of (300 $\mathrm{mM}$ ) followed by a 1 -hour incubation at $0^{\circ} \mathrm{C}$. The precipitate was pelleted by centrifugation $\left(14,000 \mathrm{rpm}, 15\right.$ minutes, $\left.4^{\circ} \mathrm{C}\right)$, the supernatant was transferred to a new tube and the DNA was precipitated by the addition of 2.5 volumes of ethanol.

The ligation was set up as follows. The linearized, dephosphorylated vector and the digested bacteriophage DNA were ligated overnight at $16^{\circ} \mathrm{C}$ with T4 DNA ligase (Pharmacia) in $20 \mu$ of One-Phor-All buffer (Pharmacia; containing: $10 \mathrm{mM}$ Tris-acetate, $10 \mathrm{mM}$ magnesium acetate, $50 \mathrm{mM}$ potassium acetate) and $1 \mathrm{mM}$ ATP. The ligase was heat-inactivated at $65^{\circ} \mathrm{C}$ for 15 minutes.

The ligation mixture was used to transform competent $E$. coli $\mathrm{DH} 5 \alpha$ cells as follows. Frozen DH5 $\alpha$ cells were thawed on ice. The ligation mixture $(5-10 \mu \mathrm{l})$ were mixed with $100 \mu \mathrm{l}$ cells, incubated on ice for 30 minutes. The mixture was then heatshocked at $42^{\circ}$ for 90 seconds and returned to ice for 15 minutes, $900 \mu 1$ SOC was added 
and the suspension was incubated for 1 hour at $37^{\circ} \mathrm{C}$ with shaking. Aliquots were plated on LB plates containing Amp, X-Gal and IPTG, which were incubated at $37^{\circ} \mathrm{C}$ overnight.

The PCR analysis was completed as follows. The recombinant clones were screened for the presence and size of inserts as follows. A portion of each isolated colonies was streaked on an Amp-containing LB plate and the remainder was resuspended in $100 \mu \mathrm{l}$ of PCR buffer containing $0.1 \%$ Triton $\mathrm{X}-100$. The suspension was then boiled for 10 minutes. PCR reactions mixtures, consisting of $1 \mu \mathrm{l}$ of boiled cells and $9 \mu \mathrm{l}$ of PCR buffer containing 2.5 units AmpiTaq Polymerase (Perkin-Elmer) and M13 primers (Pharmacia) were prepared and PCR reactions were run as described above. Aliquots of the PCR reactions were analyzed by agarose gel electrophoresis. The plasmid DNA from clones containing inserts $600 \mathrm{bp}$ or larger in size was isolated using Qiagen Tip 20 columns. The inserts were sequenced using the Sequenase version 2.0 Sequencing Kit (United States Biochemical) and M13 primers. Sets of primers for the amplification of bacteriophage DNA were designed based on the sequence information obtained from the clones.

\section{Cloning and restriction mapping}

The phage DNA was cloned into a vector in order to facilitate the restriction mapping. Flash Nonradioactive Gene Mapping Kit (Stratagene) was used for restriction mapping, as described by the manufacturer with the following modifications. A KpnI restriction site was engineered by inserting an oligonucleotide adapter into the unique BamHI site of SuperCos I (Stratagene), yielding the cosmid vector SuperKos. Bacteriophage DNA was partially digested with $K p n I$ and ligated into the KpnI-digested, gel-purified SuperKos vector. The cosmid was packaged using the Gigapack II Packaging

Extracts Kit (Stratagene) to increase the efficiency and representation of the library (Kretz et 
al., 1989). The cosmid DNA (1-4 $\mu$ l containing 0.1-5 $\mu \mathrm{g})$ was added to the freeze-thaw extract, the tube was placed on ice and $15 \mu \mathrm{l}$ of sonic extract was added. The tube was incubated at room temperature $\left(22^{\circ} \mathrm{C}\right)$ for 2 hours, then $500 \mu \mathrm{l}$ of SM buffer and $20 \mu \mathrm{l}$ of chloroform were added. The tube was centrifuged for 5 minutes at $14,000 \mathrm{rpm}$ to sediment the debris and the supernatant was titered. Dilutions of the supernatant were prepared in SM buffer (1:10 and 1:50), and added to $25 \mu \mathrm{l}$ of $E$. coli XL1-Blue MR at $\mathrm{A}_{600}$ of 0.5 . The mixture was incubated at $37^{\circ} \mathrm{C}$ for 1 hour, with gentle mixing every 15 minutes. The mixture was then centrifuged at 14,000 rpm for 1 minute and the pellet was resuspended in $50 \mu \mathrm{l} \mathrm{LB}$. The resuspension was plated on LB plates containing $75 \mu \mathrm{g} / \mathrm{ml}$ Amp. Isolated colonies were inoculated in $5 \mathrm{ml} \mathrm{LB}$ containing $75 \mu \mathrm{g} / \mathrm{ml}$ Amp and grown with shaking at $37^{\circ} \mathrm{C}$ for 8 hours. The cosmid DNA was isolated using Tip-20 columns (Qiagen). The cosmid DNA was digested with NotI to verify the presence and size of the insert. Recombinant clones were grown in $500 \mathrm{ml}$ Amp-containing $\mathrm{LB}$ at $37^{\circ} \mathrm{C}$ in a shaking incubator for 8 hours and cosmid DNA was isolated.

For mapping, HindIII sites were partially destroyed as follows: $500 \mathrm{ng}$ of each cosmid in REact 2 (Gibco BRL) were aliquotted into 1.6-ml Eppendorf microfuge tubes. The tubes were placed into a Stratalinker UV crosslinker (Stratagene) and irradiated for 15 to 45 minutes. An unirradiated sample was also prepared. The samples were then digested with HindIII (Pharmacia) to yield partial and complete digests. The restriction sites were mapped using the Flash Nonradioactive Gene Mapping Kit (Stratagene). Aliquots of 250 ng of the UV-irradiated, HindIII-digested samples were loaded in duplicate on a $0.8 \%$ TBE agarose gel and run at $50 \mathrm{~V}$ for 16 hours. The gel was photographed, and the DNA was transferred to a Nytran membrane (Schleicher and Schuell) in a TurboBlotter (Schleicher and Schuell), using the alkaline blotting procedure (Chomczynski, 1992). The blot was cut 
in half and prehybridized in prehybridization buffer $\left(50 \mu \mathrm{l}\right.$ of buffer $/ 1.0 \mathrm{~cm}^{2}$ of membrane) at $37^{\circ} \mathrm{C}$ for 10 minutes. The prehybridization buffer was removed and hybridization buffer containing either of the T3 or T7 probes (at $2 \mathrm{nM}$ ) was added. Hybridization was performed at $37^{\circ} \mathrm{C}$ for 50 minutes. The blots were then washed in 100 $\mathrm{ml}$ prewarmed wash buffer \#1 (300 mM NaCl, $35 \mathrm{mM}$ sodium citrate, 1\% (w/v) SDS) for 10 minutes at $37^{\circ} \mathrm{C}$, then in wash buffer $\# 2(300 \mathrm{mM} \mathrm{NaCl}, 35 \mathrm{mM}$ sodium citrate, $1 \%$ Triton X-100) for 10 minutes at $37^{\circ} \mathrm{C}$, then in $2 x$ SSC buffer $(350 \mathrm{mM} \mathrm{NaCl}, 35 \mathrm{mM}$ sodium citrate) for 10 minutes at room temperature. The blots were rinsed twice in assay buffer (from the kit) for 5 minutes. Substrate buffer ( $5 \mathrm{ml}$ assay buffer, $30 \mu \mathrm{l} \mathrm{CSPD}$ chemiluminescent substrate) was added to the membranes and incubated at room temperature for 5 minutes. The membranes were then placed in Saran wrap and autoradiographed. The autoradiograph was photographed and compared to the photograph of the original gel to determine band sizes. Neighboring inserts were positioned by labelling fragments located at the ends of each insert with the ECL DNA labelling kit (Amersham) and using these fragments as probes to determine the identity of adjacent fragments in hybridization experiments run with digests of either the complete phage genome or the other inserts cloned in SuperKos.

Alternatively, where possible, the complete phage genome was cloned into the SuperCos vector. Phage DNA was digested with a single-cutting restriction endonuclease and blunted if necessary (see below). SuperCos was digested with $\mathrm{XbaI}$ and BamHI, and blunted using the Klenow fragment of DNA Polymerase I (PolKI) as follows: one unit of PolKI was added per $\mu \mathrm{g}$ of DNA and the mixture was incubated at $25^{\circ} \mathrm{C}$ for 15 minutes in NEB 2 buffer (New England Biolabs) containing $33 \mu \mathrm{M}$ of each dNTP. The enzyme was inactivated by heating to $75^{\circ} \mathrm{C}$ for 10 minutes. The phage and vector DNA were blunt-end 
ligated using T4 DNA Ligase (Pharmacia) in the presence of $1 \mathrm{mM} \mathrm{ATP}$, and the reaction was carried out at $16^{\circ} \mathrm{C}$ for 16 hours. The ligation products were packaged in bacteriophage Lambda DASH II using the Gigapack II Packaging Extracts Kit (Stratagene).

Recombinant clones were screened for inserts corresponding to the complete phage genome by growing each isolated colony at $37^{\circ} \mathrm{C}$ and $300 \mathrm{rpm}$ for 8 to 12 hours in $5 \mathrm{ml} \mathrm{LB}$ supplemented with $0.2 \%$ maltose, $10 \mathrm{mM} \mathrm{MgSO}_{4}$ and $75 \mu \mathrm{g} / \mathrm{ml}$ ampicillin. The cosmid DNA was isolated using Tip-20 columns (Qiagen) and digesting the DNA with NotI to verify the insert size. Restriction sites of appropriate clones were mapped as described above.

\section{Bacteriophage protein analysis}

The CsCl-purified bacteriophages were boiled for 5 minutes in SDS loading buffer and loaded onto a 8-16\% SDS-PAGE gradient gel (Novex) which was run at $150 \mathrm{~V}$ for 2.5 hours. Gels were stained either with Coomassie Brilliant Blue R250 (Sigma) or with the Bio-Rad Silver Stain Kit as follows. After gel electrophoresis, gels were placed in the Fixative Enhancer Solution (methanol, 50\% (vol/vol); acetic acid, 10\% (vol/vol); Fixative Enhancer Concentrate, $10 \%$ (vol/vol); deionized water, $30 \%$ (vol/vol)) and fixed for 20 minutes with gentle agitation. The Fixative Enhancer Solution was decanted from the staining vessel, and the gels were rinsed twice with $400 \mathrm{ml}$ deionized water for 10 minutes with gentle agitation. The staining solution $(5 \mathrm{ml}$ Silver Complex, $5 \mathrm{ml}$ Reduction Moderator Solution, $5 \mathrm{ml}$ Image Development Reagent and $50 \mathrm{ml}$ room temperature Development Accelerator Solution) was prepared within 5 minutes of use. Gels were stained for approximately 20 minutes or until desired staining intensity was reached. The gels were placed in 5\% acetic acid for 15 minutes to stop the reaction and rinsed in 
NANOpure water for 5 minutes. The gels were then dried and photographed.

\section{Electron Microscopy}

A $50 \mu \mathrm{l}$ drop of $\mathrm{CsCl}$-purified bacteriophages ( $1 \times 10^{7} \mathrm{pfu}$ ) was deposited on the Formvar-coated, carbon-reinforced copper grid for 2 minutes. The excess liquid was wicked off with filter paper (Whatman), and a $1 \%$ aqueous uranyl acetate solution was deposited onto the grid for 1 minute, the excess was wicked off with filter paper, and air dried for 5 minutes. The grids were examined and photographed in a Zeiss transmission electron microscope, at $80 \mathrm{kV}$. Dimensions were measured on 25 particles per bacteriophage. 


\section{Results}

\section{Isolation of various bacteriophages from two strains of Bacillus thuringiensis subspecies kurstaki}

In this study, two strains of $B$. thuringiensis subspecies kurstaki, which is probably the most widely used $B$. thuringiensis subspecies in large-scale fermentation, were selected. The two strains used were HD119, originally isolated by H. D. Burges, and HD942 isolated by N. R. Dubois, and were chosen due to their propensity to lyse on nutrient plates in areas of high cell density. Lysis was even more apparent on plates inoculated with recombinant derivatives of these two strains (data not shown), containing either plasmid vectors (pSB909.5, Gamel and Piot, 1992) harboring additional cry genes, or derivatives containing cry genes integrated into the chromosome (Sue Kalman, personal communication). Such a phenomenon can be seen in Figure 1.

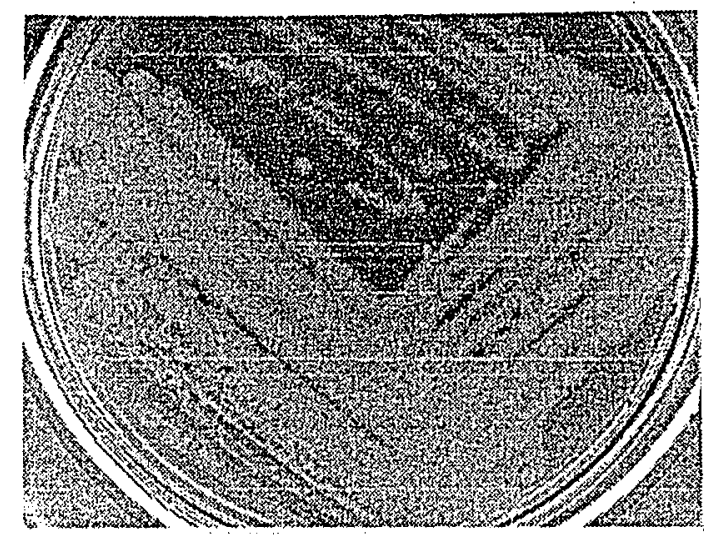

Figure 1. Lysis of culture growth of B. thuringiensis subspecies kurstaki HD119 


\section{Optimization of induction parameters}

Exponentially growing cultures of HD119 and HD942 were induced with either UV irradiation or incubation with MMC. Initially, several irradiation times or MMC concentrations were used with HD942 in order to determine the optimal conditions for bacteriophage development. Those times and concentrations which gave the most reproducible results were selected for further experiments with HD119 and HD942. Growth and lysis curves of cultures of HD942 induced with various doses of UV or MMC are shown in Figure 2. 


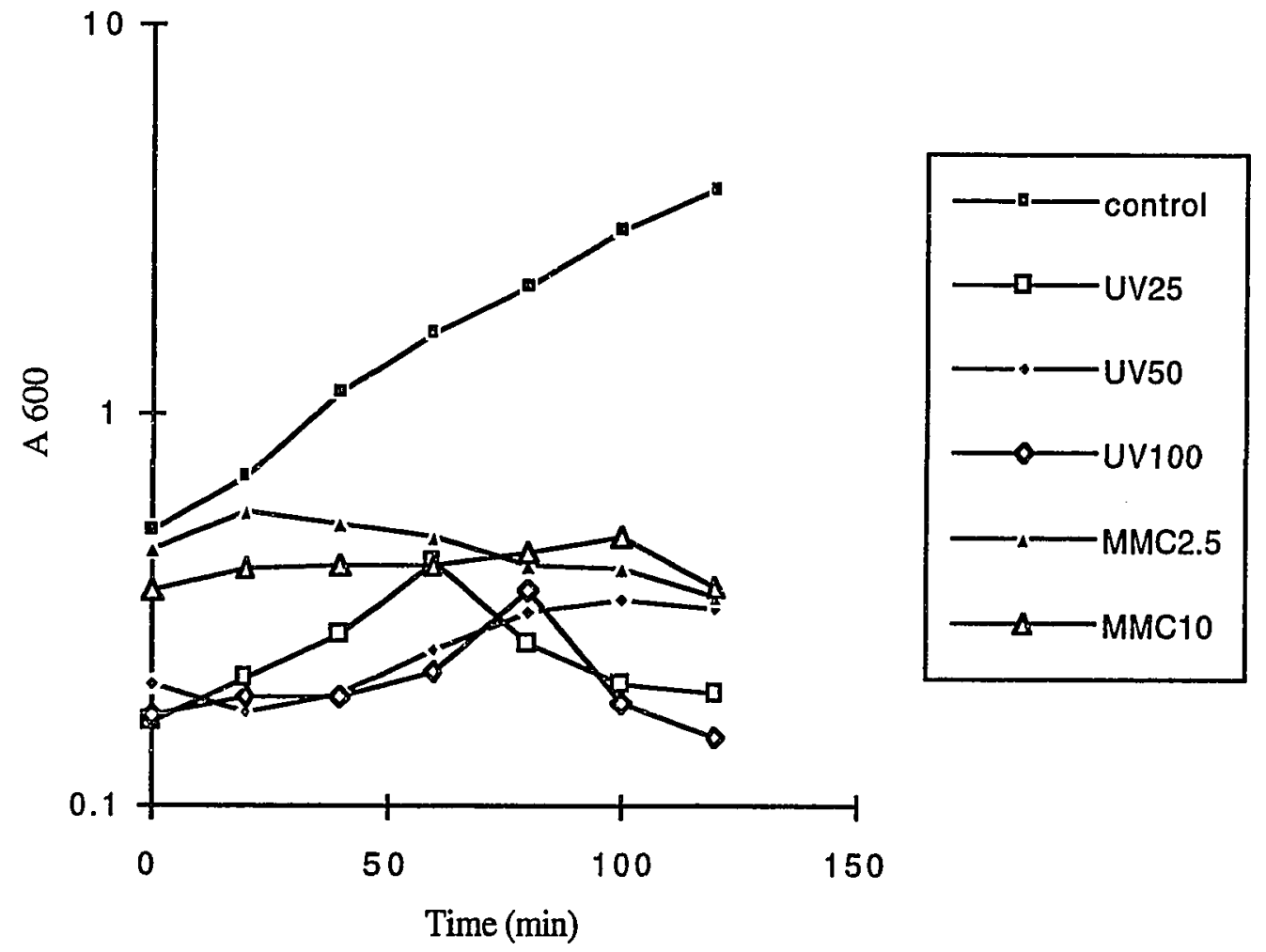

Figure 2. Induction of HD942 through ultraviolet irradiation or incubation with mitomycin C. Exponentially growing cultures were exposed to UV light for the time indicated or to MMC at the final concentration given in the legend. The $A_{600}$ was measured at 20 - minute intervals. 0 minutes: Time of induction. 
As shown in Figure 2, the higher doses of inducing agent slowed growth rates immediately, as shown by the difference in $\mathrm{A}_{600}$ at the time when the induced (time 0 ) and non-induced cells were resuspended in culture media, shown as the first data point obtained after time 0 . The effect was most evident with the UV treatment, and the cultures irradiated with the higher doses took longer to resume growth, maybe because of high mortality. In most cases, lysis occurred between 100 and 120 minutes after induction. On the other hand, for the MMC-treated cultures, the effect on growth was not as severe and lysis was not as rapid as with UV. The general shape of the induction curve was, however, quite different from the shape of the curve obtained when inducing other prophages such as PBSX and related phages from Bacillus subtilis (Manuel and Karamata, 1984). Indicating either an asynchronous development of the induced bacteriophage(s), or other unknown problems.

In order to evaluate the efficiency of the induction process, as represented by the bacteriophage titers, the culture lysates obtained above were serially diluted and aliquots were mixed with spores of $B$. cereus 569 and plated. Results are shown in Table 1.

Table 1. Bacteriophage yields following induction with ultraviolet irradiation or MMC treatment.

\begin{tabular}{lll}
\hline \multicolumn{2}{l}{ Treatment } & pfu/ml \\
\hline Control & $4.7 \times 10^{6}$ \\
UV & $25 \mathrm{~s}$ & $7.5 \times 10^{7}$ \\
& $50 \mathrm{~s}$ & $4.6 \times 10^{7}$ \\
& $100 \mathrm{~s}$ & $7.0 \times 10^{5}$ \\
MMC & $2.5 \mu \mathrm{g} / \mathrm{ml}$ & $3.8 \times 10^{7}$ \\
& $10 \mu \mathrm{g} / \mathrm{ml}$ & $1.6 \times 10^{7}$ \\
\hline
\end{tabular}


The results in Table 1 show that the highest titers were obtained when the cultures were induced with $2.5 \mu \mathrm{g} / \mathrm{ml} \mathrm{MMC}$ or irradiated for 25 seconds with UV light, and these conditions were selected for experiments with HD942 and HD119 (Figures 3 and 4). Noteworthy is the fact that even the non-induced culture contained significant numbers of phages, consistent with the original observation that spontaneous lysis could take place on nutrient plates.

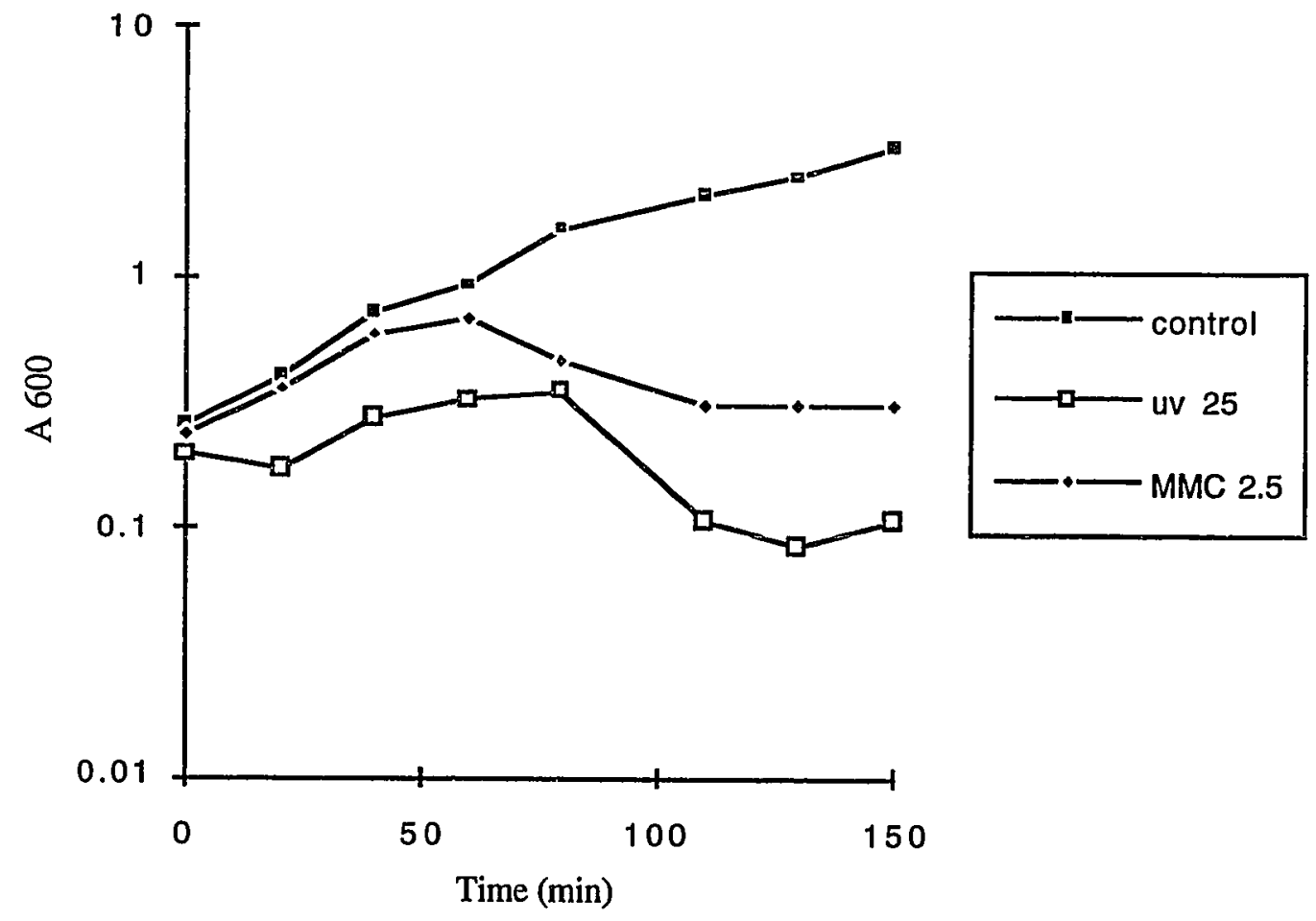

Figure 3. HD942 induction with ultraviolet irradiation for 25 seconds or mitomycin C treatment at $2.5 \mu \mathrm{g} / \mathrm{ml}$. 


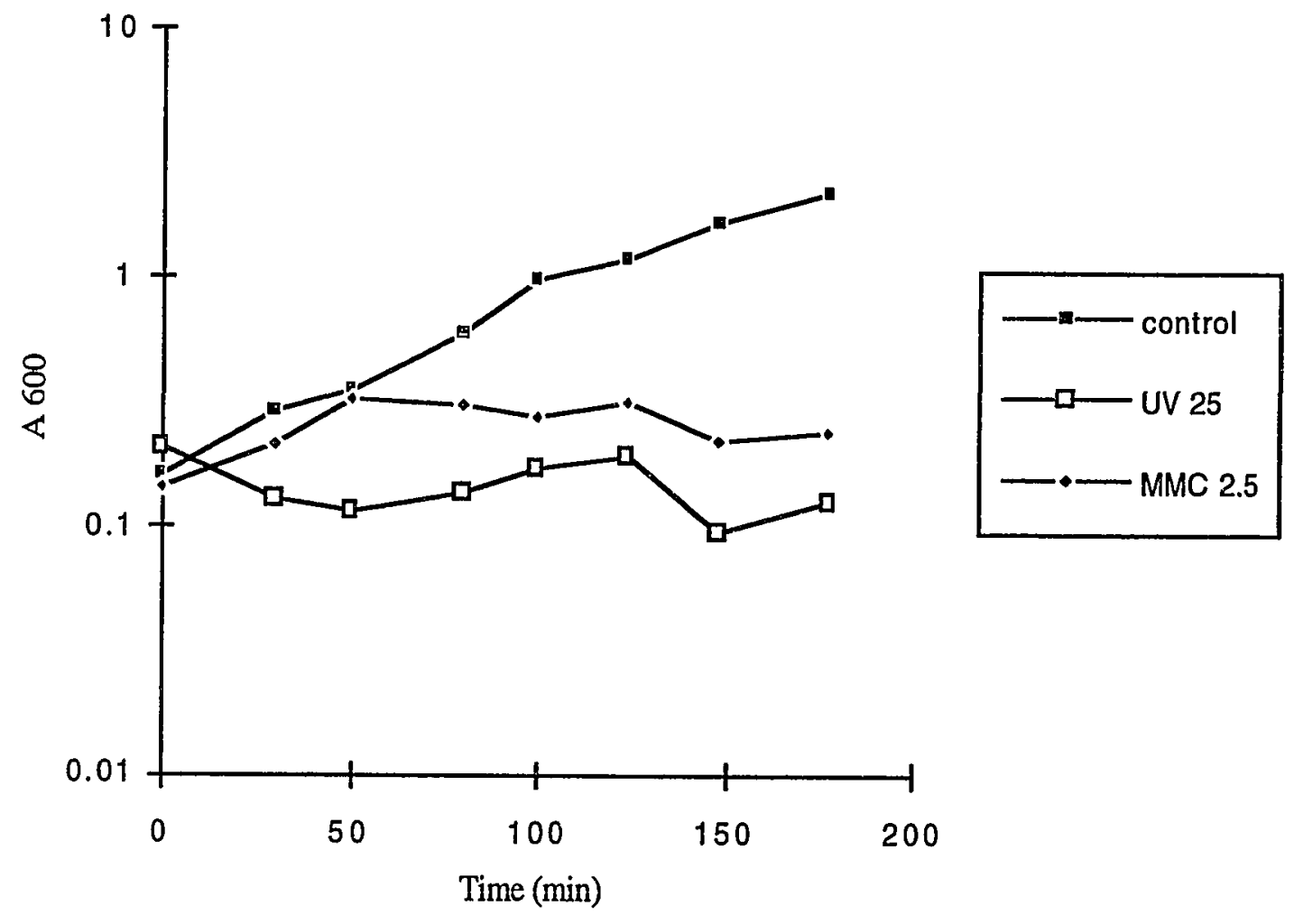

Figure 4. HD1 19 induced with ultraviolet 25 seconds, mitomycin C $2.5 \mu \mathrm{g} / \mathrm{ml}$. 


\section{Isolation of several types of bacteriophages with distinct plaque morphologies}

When the lysates obtained in the previous experiment were plated as described, several morphologically distinct plaque types were obtained. These morphologies are presented in Table 2.

Table 2. Plaque types obtained from B. thuringiensis HD119 and HD942 induced cultures.

\begin{tabular}{lll}
\hline $\begin{array}{l}\text { B. thuringiensis } \\
\text { strain induced }\end{array}$ & $\begin{array}{l}\text { Plaque } \\
\text { morphology }\end{array}$ & $\begin{array}{l}\text { Bacteriophage } \\
\text { designation }\end{array}$ \\
\hline HD942 & small, clear & $\emptyset 6-5.1$ \\
& small, turbid & $\varnothing 6-2$ \\
& small, turbid, clear center & $\emptyset 6-1$ \\
& large, turbid & $\varnothing 6-3$ \\
& turbid, raised center & $\varnothing 6-4$ \\
large, turbid, derivative $\varnothing 6-5$ & $\varnothing 6-5.3$ \\
& small, clear & $\emptyset 12-1$ \\
& small, turbid & $\emptyset 12-2$ \\
& large, turbid & $\varnothing 12-3$ \\
& large, turbid, raised center & $\emptyset 12-7$ \\
\hline
\end{tabular}

The types of plaques obtained reflect the major subdivision among the bacteriophages, namely the existence of virulent and temperate phages. Virulent phages 
lyse the bacteria they infect, producing a clear plaque. On the other hand, temperate phage often produce turbid plaques since some cells that are infected are not lysed.

Each type of plaque was further purified on a lawn of $B$. cereus 569 until a single plaque morphology could be detected; at this point the bacteriophage suspension was considered pure. Interestingly, one phage, Ø6-5, gave rise to morphological variants after purification. When the clear plaque-producing bacteriophage was purified through subculturing, variants producing large turbid plaques could be detected at a frequency of about $10^{-4}$. This phenotype was stable upon subculturing, and the clear plaque phage and the turbid plaque mutant were given the designations $\varnothing 6-5.1$ and $\varnothing 6-5.3$ respectively.

In order to obtain sufficient numbers of bacteriophages, the pure suspensions were plated on a lawn of $B$. cereus 569 . Upon plaque development, the overlay was scraped off the plates and macerated. The dense mixture of B. cereus 569 cells, agar, and bacteriophages was centrifuged, and the supernatant containing the bacteriophages was collected and titered on a lawn of $B$. cereus 569 .

\section{Lysogenization of $B$. cereus 569}

A droplet containing $1 \times 10^{3}$ to $1.8 \times 10^{5}$ pfu was deposited ("spotted") on a lawn of B. cereus 569 spores. As expected, the suspensions containing plaque-forming units (pfu) which originally yielded turbid plaques also produced turbid spots, indicating the temperate nature of the bacteriophage. On the other hand, the two clear plaque-producing suspensions yielded clear spots, but some islands of apparently resistant bacteria were observed on the edge of the spots. The presence of the islands could indicate either growth of cells resistant to the bacteriophages or cells that were immune to them and hence lysogenic. In order to determine whether lysogens had been obtained, cells were taken 
from the center of the turbid spots or from the islands described above and streaked on a nutrient plate. A number of isolated colonies were obtained and examined for their sensitivity to bacteriophage infection. The colonies were individually resuspended in a small volume of media which was then overlaid on a nutrient plate. Once set, the same bacteriophage suspension which was originally used to obtain these isolates was spotted on the lawn. Although a number of isolates still were susceptible to the bacteriophage, as shown by the presence of a spot, several isolates did not show any clearing and were further examined for their ability to yield bacteriophages upon induction. The induction procedure was essentially the same as the one used for $B$. thuringiensis, except that only MMC was used as an inducing agent. Three concentrations of MMC were first evaluated in order to optimize pfu yields. Results of these preliminary experiments run with $B$. cereus 569::Ø6-2 are presented in Table 3.

Table 3. Phage titers obtained with various mitomycin $\mathrm{C}$ concentrations on $B$. cereus $569:: \varnothing 6-2$.

\begin{tabular}{ll}
\hline MMC treatment & pfu/ml \\
\hline control & $1.1 \times 10^{7}$ \\
$0.1 \mu \mathrm{g} / \mathrm{ml}$ & $3.9 \times 10^{10}$ \\
$1 \mu \mathrm{g} / \mathrm{ml}$ & $2.5 \times 10^{10}$ \\
$10 \mu \mathrm{g} / \mathrm{ml}$ & $1.0 \times 10^{8}$ \\
\hline
\end{tabular}


As shown in Table 3, the highest yields were obtained when the lysogens were induced with $0.1 \mu \mathrm{g} / \mathrm{ml}$ or $1 \mu \mathrm{g} / \mathrm{ml} \mathrm{MMC}$; however, $1 \mu \mathrm{g} / \mathrm{ml}$ gave more reproducible results (not shown), probably due to the instability of MMC. This concentration was used throughout the rest of the study.

For the purpose of biochemical characterization and bacteriophage typing, significant amounts of the various bacteriophages were needed. To that end, each of the $B$. cereus 569 lysogens was induced with MMC. The induction curves are presented in Figures 5 and 6. 


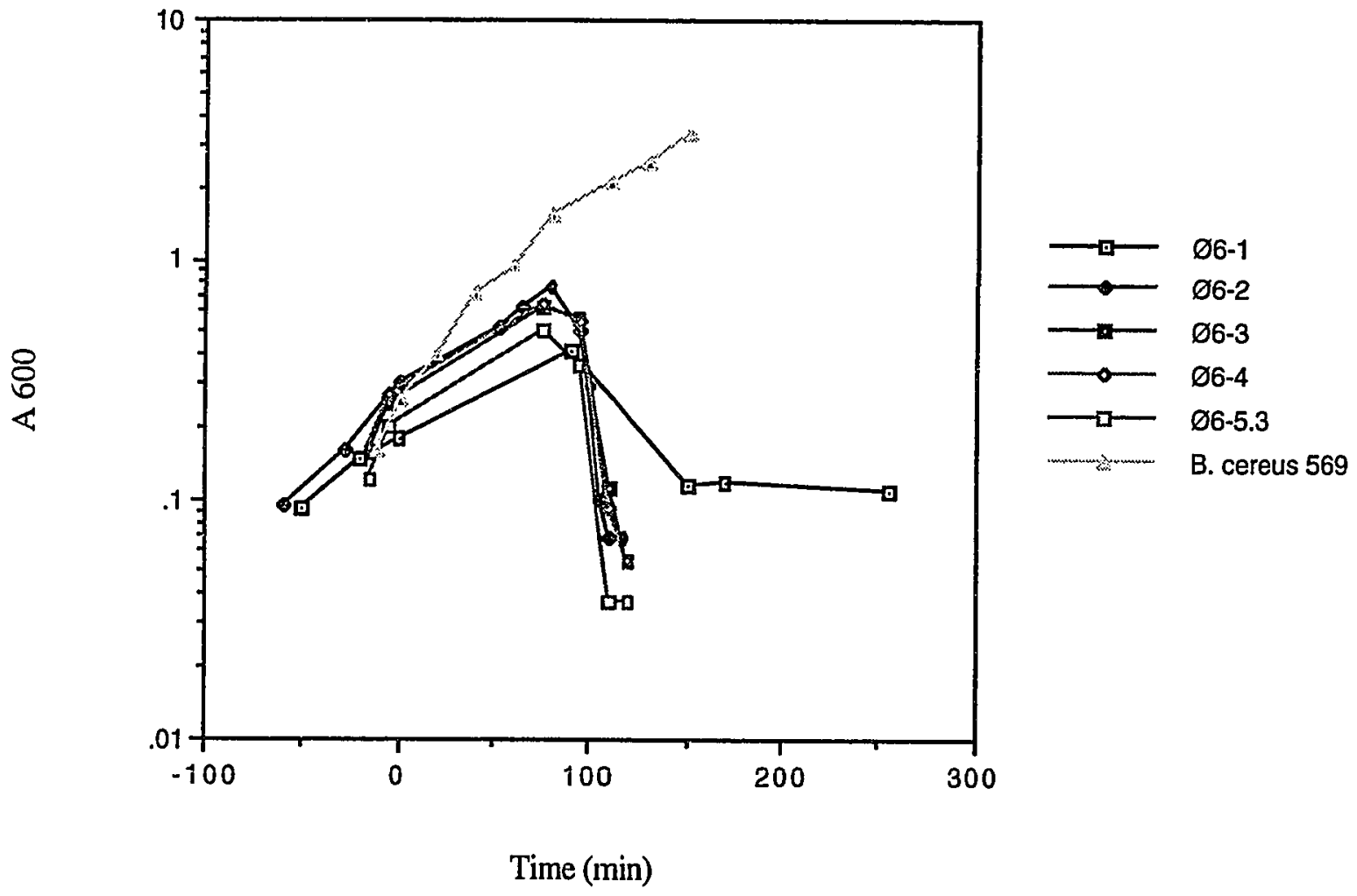

Figure 5. B. cereus 569 lysogens 6-1, 6-2, 6-3 and 6-5.3 induced with $1 \mu \mathrm{g} / \mathrm{ml}$ mitomycin C. 


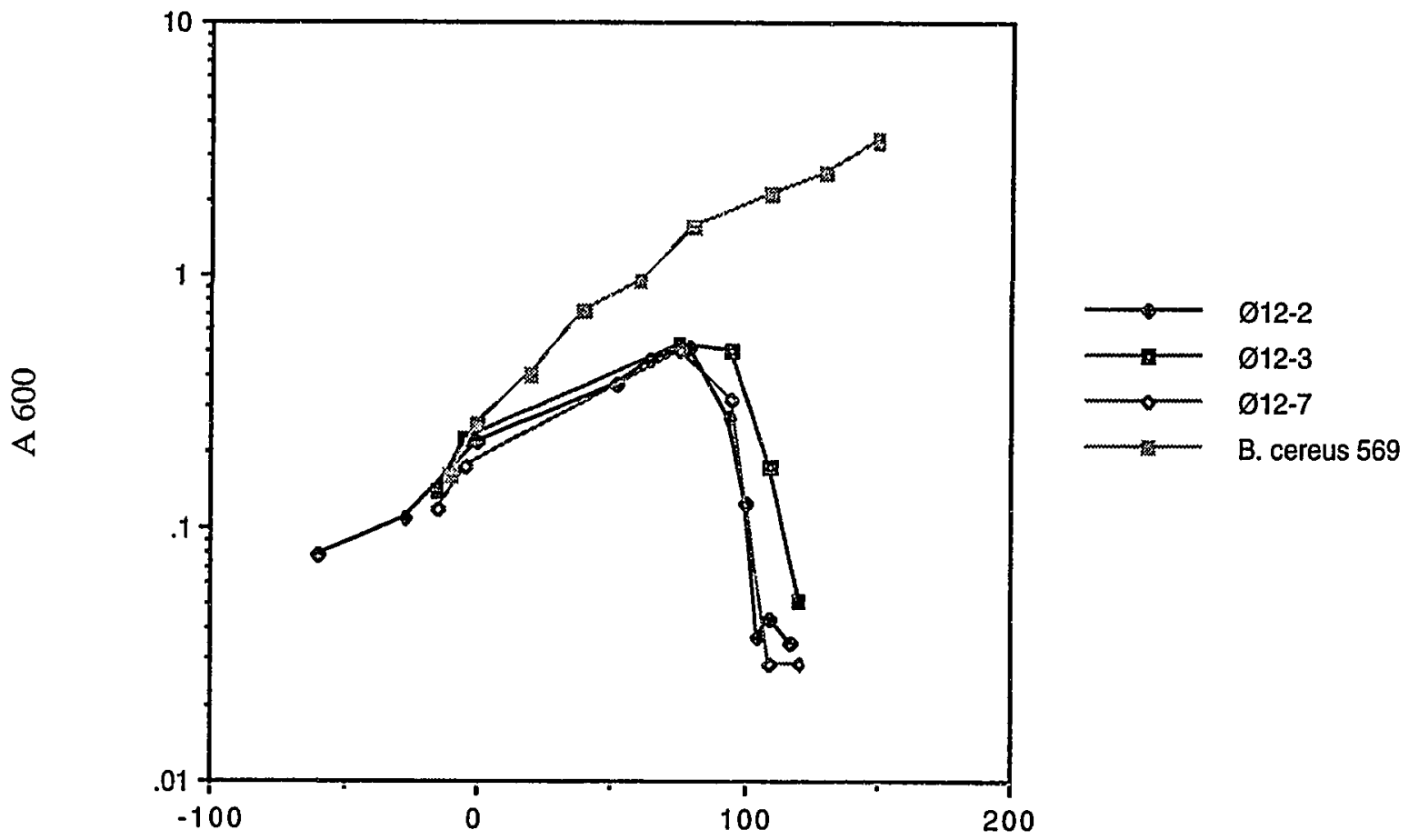

Time (min)

Figure 6. B. cereus 569 lysogens $12-2,12-3$ and $12-7$ induced with $1 \mu \mathrm{g} / \mathrm{ml}$ mitomycin C. 
In contrast with what was observed when $B$. thuringiensis was induced, the lysis pattern of many of the lysogenic strains was reminiscent of that obtained in other systems such as PBSX in Bacillus subtilis (Manuel and Karamata, 1984). However, the notable exception was the strain harboring Ø6-1, which did not lyse as well as the others.

The titers of the crude lysates were determined by plating aliquots on $B$. cereus 569. These results are presented in Table 4.

Table 4. Bacteriophage titers obtained after induction of B. cereus 569 lysogens with 1 $\mu \mathrm{g} / \mathrm{ml}$ mitomycin C.

\begin{tabular}{cl}
\hline Bacteriophage & $\mathrm{pfu} / \mathrm{ml}$ \\
\hline$\varnothing 6-1$ & $4.7 \times 106$ \\
$\varnothing 6-2$ & $9 \times 10^{10}$ \\
$\emptyset 6-3$ & $1.2 \times 1011$ \\
$\emptyset 6-4$ & $6.7 \times 1010$ \\
$\varnothing 6-5.3$ & $4.5 \times 1010$ \\
$\emptyset 12-2$ & $2.5 \times 1010$ \\
$\emptyset 12-3$ & $2.1 \times 1010$ \\
$\varnothing 12-7$ & $3.1 \times 1010$ \\
\hline
\end{tabular}

Since no B. cereus 569 lysogens could be obtained with the two virulent bacteriophages, $\varnothing 6-5.1$ and $\emptyset 12-1$, an alternative method was used for propagation of these two phages (see Materials and methods). Several multiplicities of infection (m. o. i., ratio of bacteriophage/bacteria) were tested in order to determine the conditions giving the highest yields of bacteriophages. Results of experiments run with ø6-5.1 are shown in 
Figure 7 and Table 5.

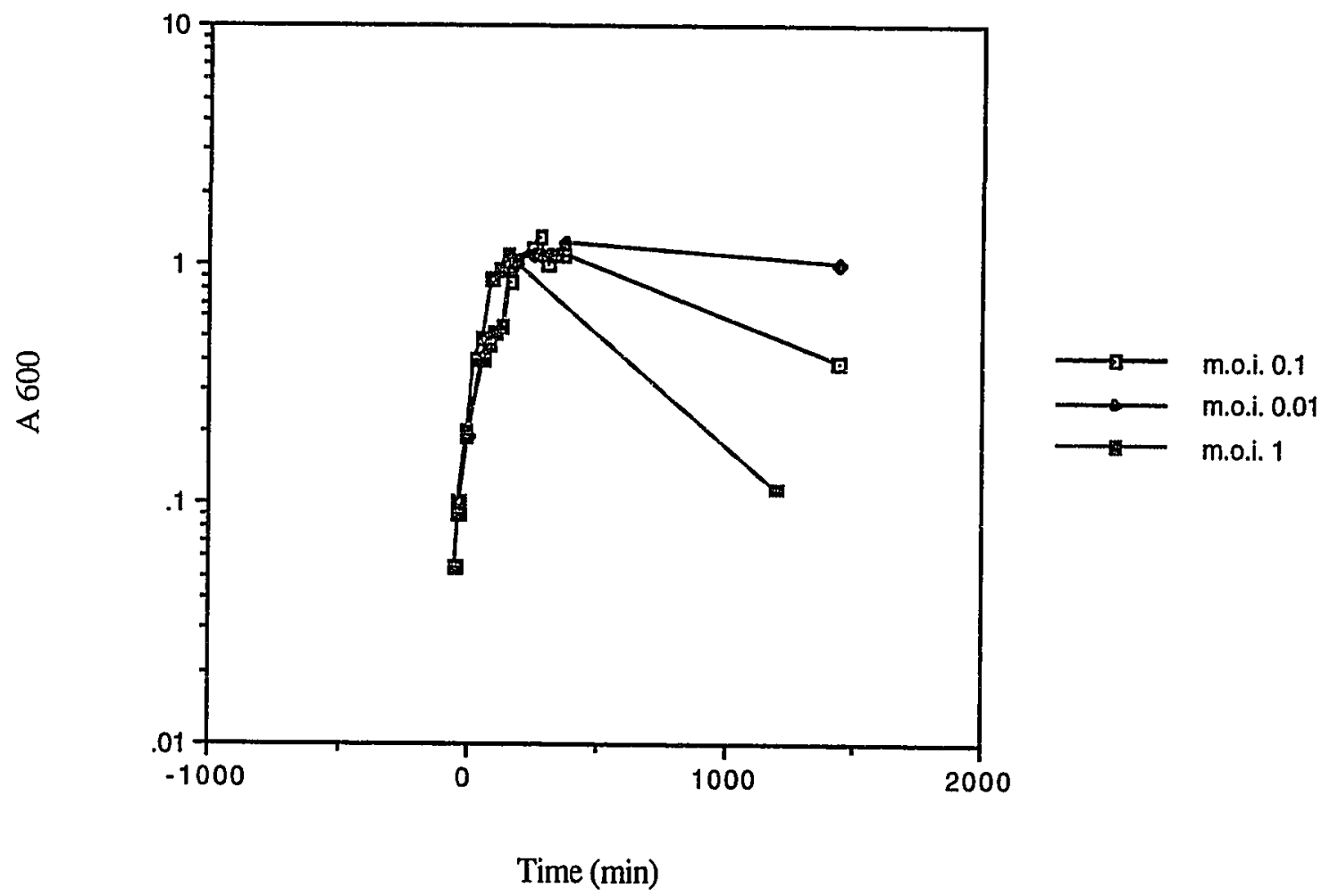

Figure 7. $\mathrm{A}_{600}$ of $B$. cereus 568 lysogen of $\emptyset 6-5.1$ at various time points, m. o. i. 0.1, 0.01 , and 1 . 
Table 5. Yields of bacteriophage obtained from cultures infected with $\emptyset 6-5.1$ at various m. o. i.

\begin{tabular}{cll}
\hline m.o.i & titer liquid (a) & titer plate (b) \\
\hline 1 & $6 \times 108$ & $1.95 \times 10^{10}$ \\
0.1 & $1 \times 108$ & $3.4 \times 10^{10}$ \\
0.01 & $1 \times 108$ & $1.5 \times 10^{10}$ \\
\hline
\end{tabular}

(a): titers obtained from cultures after an overnight incubation in liquid medium. (b): titers obtained after a further round of multiplication in soft PA agar, where the lysates from (a) were plated on the PA plates, with the addition of $1 \times 10^{8}$ B. cereus 569 spores if the culture was cleared.

A m. o. i. of $\mathbf{I}$ gave confluent lysis of the B. cereus 569 lawn and gave high, consistent titers for both $\varnothing 6-5.1$ and $\varnothing 12-1$. The highest titers were obtained when a phage-host mixture is used which gives almost confluent lysis at the time of maximum growth of the host. The results presented in Figure 7 and Table 5 show that although $\mathrm{m}$. 0 . i. ranging from 0.01 to 1 were used, the titers obtained from liquid cultures infected with bacteriophages $\varnothing 6-5.1$ vary only by a factor of about five, and that titers obtained from the plates by a factor of about two.

Genetic and biochemical characterization were carried out on the bacteriophages obtained by this method. Eventually, B. cereus 569 lysogens were acquired for bacteriophages 6-5.1 and $\varnothing 12-1$ and the biochemical and genetic characterizations were 
repeated with these bacteriophages. The induction graphs and titers are shown in Figure 8 and Table 6.

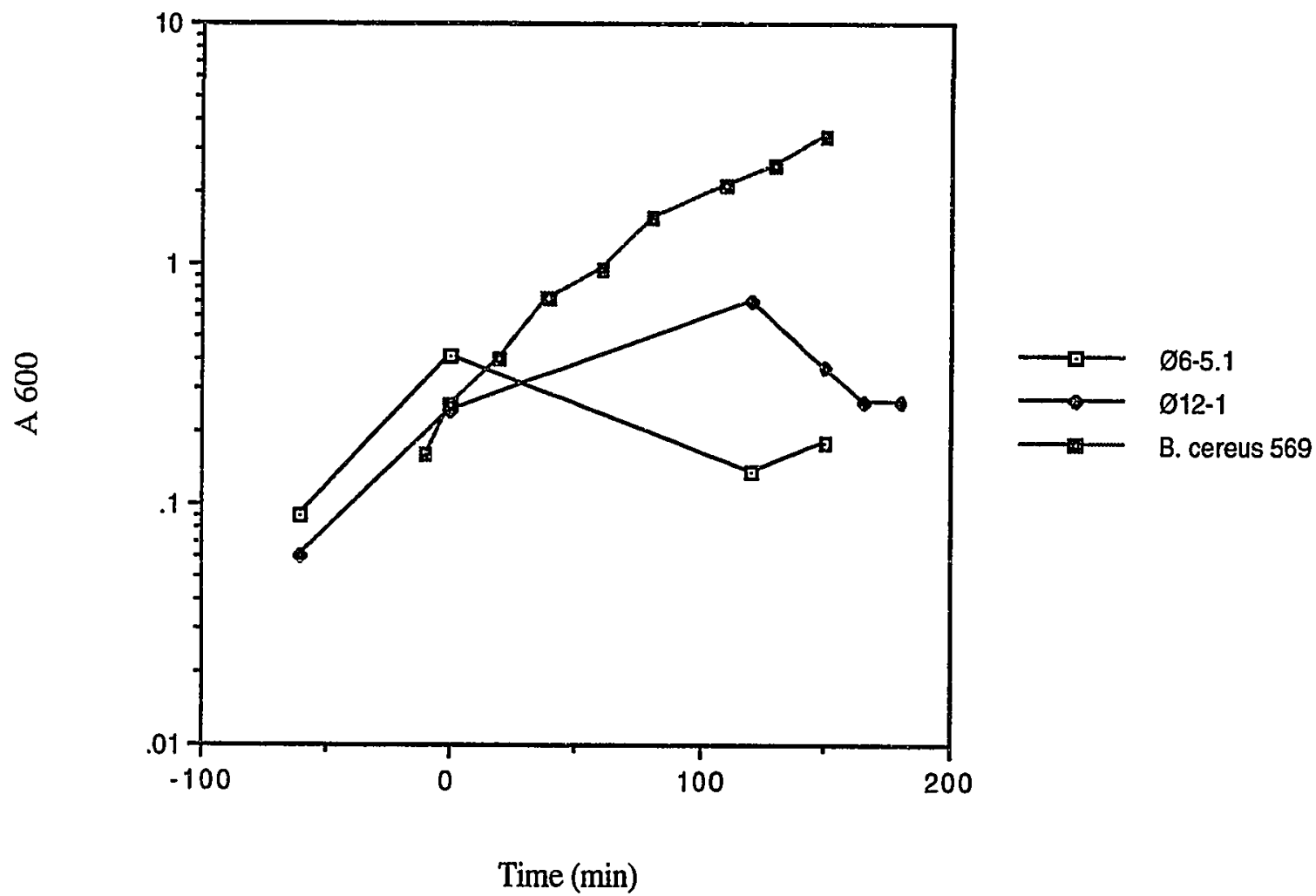

Figure 8. B. cereus 569 lysogens of bacteriophage $\emptyset 6-5.1$ and $\varnothing 12-1$ induced with 1 $\mu \mathrm{g} / \mathrm{ml}$ mitomycin $\mathrm{C}$. 
Table 6. Bacteriophage $\varnothing 6-5.1$ and $\varnothing 12-1$ titers obtained after induction of $B$. cereus 569 lysogens with $1 \mu \mathrm{g} / \mathrm{ml}$ mitomycin $\mathrm{C}$.

\begin{tabular}{cc}
\hline Bacteriophage & $\mathrm{pfu} / \mathrm{ml}$ \\
$\varnothing 6-5.1$ & $4 \times 10^{9}$ \\
$\varnothing 12-1$ & $1.6 \times 10^{10}$ \\
\hline
\end{tabular}

However, the prophage obtained from the induction of lysogenic B. cereus 569 of bacteriophage $\emptyset 6-5.1$ and $\varnothing 12-1$ differed from the original bacteriophage obtained from the m. o. i. method (see Biochemical and genetic characterization section).

\section{Phage typing (cross spotting)}

In order to determine whether the various types of bacteriophages were related to each other, each phage suspension was spotted on a lawn containing spores of each of the lysogens. Results of this phage typing experiment are presented in Table 7. 
Table 7. Phage typing (cross-spotting).

\begin{tabular}{|c|c|c|c|c|c|c|c|c|c|c|}
\hline \multirow[t]{2}{*}{$\begin{array}{l}\text { Phage } \\
\text { suspension }\end{array}$} & & \multicolumn{9}{|c|}{$\begin{array}{l}\text { Indicator } \\
\text { strain }\end{array}$} \\
\hline & Bc 569 & $\varnothing 6-1$ & $\varnothing 6-2$ & $\varnothing 6-3$ & $\varnothing 6-4$ & $\varnothing 6-5.1$ & $\varnothing 6-5.3$ & $\varnothing 12-1$ & $\varnothing 12-2$ & $\varnothing 12-7$ \\
\hline$\emptyset 6-1$ & + & - & + & + & + & - & + & - & + & + \\
\hline ø6-2 & + & + & - & - & - & + & - & - & - & - \\
\hline$\varnothing 6-3$ & + & + & - & - & - & + & - & - & - & - \\
\hline$\varnothing 6-4$ & + & + & - & - & - & + & - & - & - & - \\
\hline$\varnothing 6-5.1(a)$ & + & + & + & + & + & + & + & + & + & + \\
\hline$\varnothing 6-5.3$ & + & + & - & - & - & + & - & - & - & - \\
\hline$\emptyset 12-1(a)$ & + & + & + & + & + & - & + & - & + & + \\
\hline$\varnothing 12-2$ & + & + & - & - & - & + & - & - & - & - \\
\hline$\varnothing 12-3$ & + & + & - & - & - & + & - & - & - & - \\
\hline$\emptyset 12-7$ & + & + & - & - & - & + & - & - & - & - \\
\hline$\varnothing 6-5.1(\mathrm{~b})$ & + & + & + & + & + & + & + & + & + & + \\
\hline$\emptyset 12-1$ (b) & + & + & + & + & + & + & + & - & + & + \\
\hline
\end{tabular}

$(+)$ : lysis of indicator; (-): no lysis of indicator; (a): lysates obtained from plates; (b): lysates obtained from induced $B$. cereus 569 lysogen. 
From the results presented in Table 7, it can be concluded that phages $\varnothing 6-2, \varnothing 6-3$, $\varnothing 6-4, \varnothing 6-5.3, \varnothing 12-2, \varnothing 12-3$, and $\varnothing 12-7$ are closely related, if not identical, since the lysogens harboring those phages are immune to superinfection with the other phages in that group. Therefore, $\varnothing 6-2$ was selected as the prototype. Other groups comprised phages $\varnothing 6-5.1(\mathrm{a}), \varnothing 6-5.1(\mathrm{~b})$ and $\varnothing 12-1(\mathrm{a}), \varnothing 12-1(\mathrm{~b})$ and $\varnothing 6-1$, respectively and were selected for further studies.

Biochemical and genetic characterization of bacteriophages isolated from $B$. thuringiensis subspecies kurstaki HD119 and HD942

\section{Large scale purification of $\varnothing 6-1, \varnothing 6-2, \varnothing 6-5.1$ and $\varnothing 12-1$}

In order to obtain large concentrations of each phage for protein and DNA analysis each lysogen was grown in a 2 liter flask containing $500 \mathrm{ml}$ of medium. The induction curves and titers obtained in these experiments are shown in Figure 9 and Table 8. 


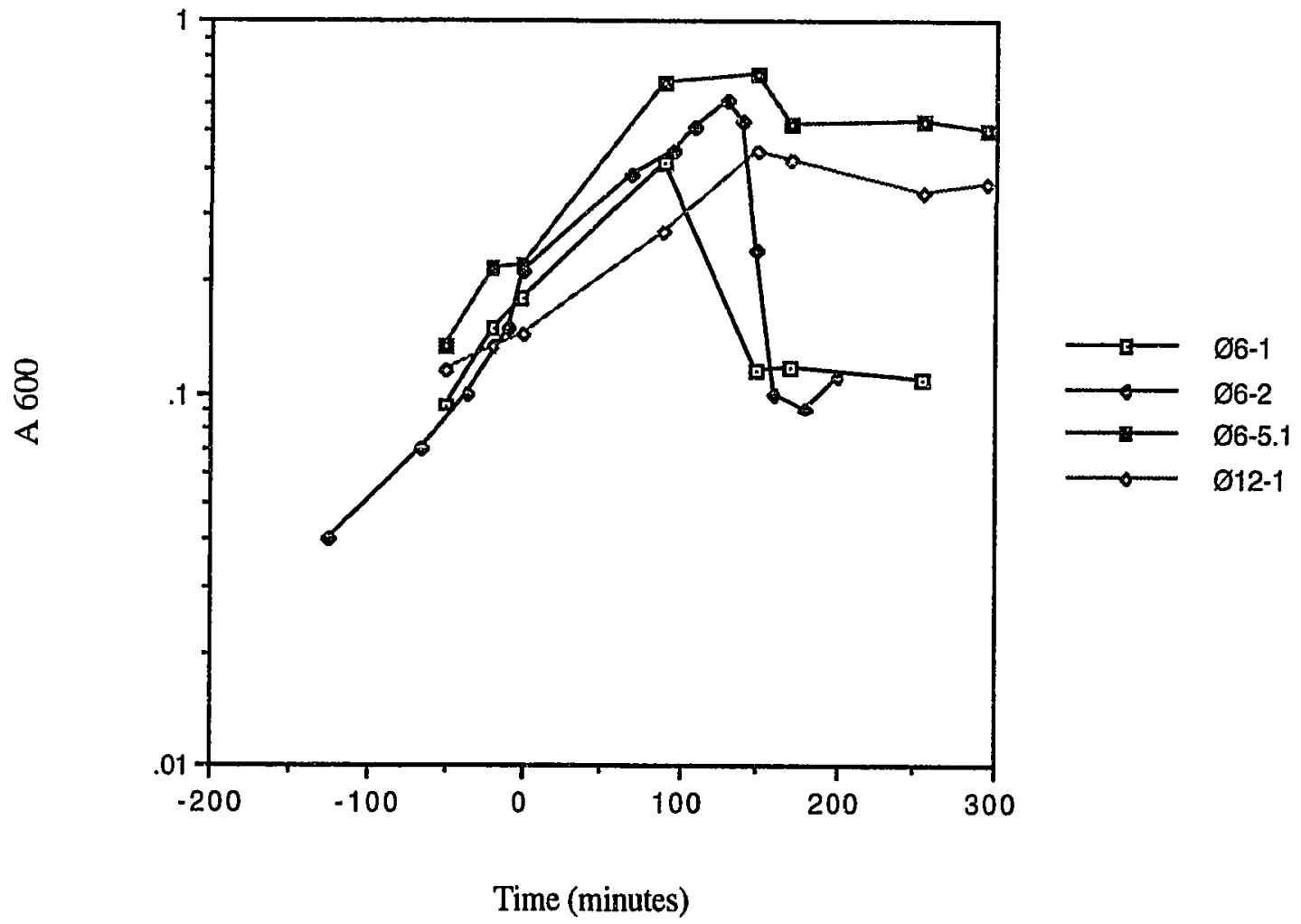

Figure 9. Induction of $B$. cereus 569 lysogens, $500 \mathrm{ml}$ cultures. The cultures were induced at time $=0$ with $1 \mu \mathrm{g} / \mathrm{ml} \mathrm{MMC}$. 
Table 8. Phage titers obtained from 500-ml cultures of B. cereus 569 lysogens induced with $1 \mu \mathrm{g} / \mathrm{ml}$ mitomycin $\mathrm{C}$.

\begin{tabular}{ll}
\hline Bacteriophage & $\mathrm{pfu} / \mathrm{ml}$ \\
\hline$\varnothing 6-1$ & $4.7 \times 10^{6}$ \\
$\varnothing 6-2$ & $2.8 \times 10^{10}$ \\
$\varnothing 6-5.1$ & $2 \times 10^{7}$ \\
$\varnothing 12-1$ & $2 \times 10^{6}$ \\
\hline
\end{tabular}

Due to the relatively low titers for all of the phage lysates obtained from the large-scale cultures, except $\varnothing 6-2$, as opposed to those obtained from small scale inductions, the induction experiments were repeated with $100-\mathrm{ml}$ cultures grown in 500-ml flasks. Titers obtained in these experiments were higher (Table 9). 
Table 9. Phage titers obtained after induction of B. cereus 569 lysogens grown in $100 \mathrm{ml}$ cultures.

\begin{tabular}{ll}
\hline Bacteriophage & $\mathrm{pfu} / \mathrm{ml}$ \\
\hline$\varnothing 6-1$ & $7 \times 10^{7}$ \\
$\varnothing 6-2$ & $9 \times 10^{10}$ \\
$\varnothing 6-5.1$ & $5 \times 10^{9}$ \\
$\varnothing 12-1$ & $3 \times 10^{9}$ \\
\hline
\end{tabular}

The cultures were induced with $1 \mu \mathrm{g} / \mathrm{ml} \mathrm{MMC}$ at $\mathrm{T}=0$.

The decrease in the culture size resulted in all the cases in an increase in the phage titers The increase ranged from about 3-fold for $\varnothing 6-2$ to over a 1000 -fold for $\varnothing 12-1$, indicating a possible effect of the growth rate limitation due to insufficient aeration on the outcome of bacteriophage development. Following this finding, the lysogens were grown in $100 \mathrm{ml}$ cultures for all subsequent induction experiments.

\section{Cesium chloride gradient purification of bacteriophage stocks}

After concentration from the crude lysates, the phage stocks were loaded onto preformed, discontinuous cesium chloride $(\mathrm{CsCl})$ gradients as described in the Materials and Methods section. After centrifugation, an iridescent bluish band, characteristic of concentrated bacteriophage stocks could be seen at different locations in the gradients depending on the phage (Figure 10). 
lane

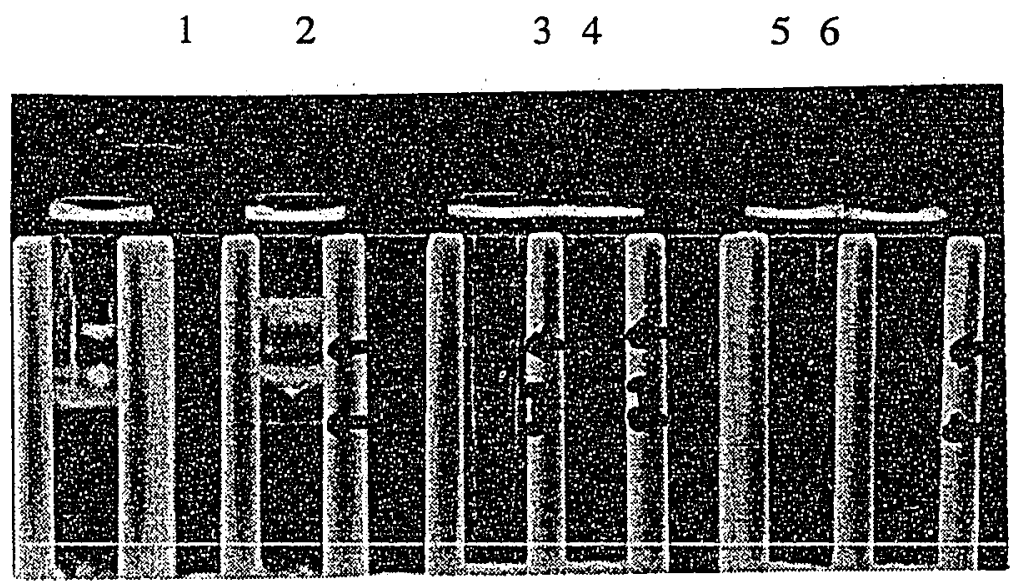

$\begin{array}{lll}\text { lane } & 1 & \varnothing 6-1 \\ 2 & \varnothing 6-2 \\ 3 & \varnothing 6-5.1(a) \\ 4 & \varnothing 6-5.1(a) \\ 5 & \varnothing 12-1(a) \\ 6 & \varnothing 12-1(a)\end{array}$

Figure 10. $\mathrm{CsCl}$ gradients of concentrated bacteriophage stocks. 1). Ø6-1,2). Ø6-2, 3 and 4). Ø6-5.1, and 5 and 6). Ø12-1. The pictures were taken after a 4 hour centrifugation. (a): phage obtained by infection of $B$. cereus 569 spores. 
Since there were major differences in the appearance of the bands in the gradients, the recovery yields were determined. The results are shown in Table 10.

Table 10. Recovery of bacteriophage applied to cesium chloride gradients.

\begin{tabular}{llll}
\hline Bacteriophage & pfu loaded & pfu recovered & $\begin{array}{l}\text { yield } \\
\text { pfu loaded/pfu recovered }\end{array}$ \\
\hline$\varnothing 6-1$ & $1 \times 10^{6}$ & $8 \times 105$ & 1.25 \\
$\varnothing 6-2$ & $2 \times 10^{13}$ & $3.2 \times 10^{12}$ & 6.25 \\
$\varnothing 6-5.1$ & $2.7 \times 10^{9}$ & $2.4 \times 10^{6}$ & 1125 \\
$\varnothing 12-1$ & $2.4 \times 10^{10}$ & $1.3 \times 10^{6}$ & 18462 \\
\hline
\end{tabular}

\section{Morphological characterization of the bacteriophages}

After purification on $\mathrm{CsCl}$ gradients, the bacteriophages were visualized by transmission electron microscopy (TEM), using the negative contrast staining technique. Pictures of the representative samples are shown in Figure 11. The dimensions of the phages were also measured and are given in Table 11. 
A.

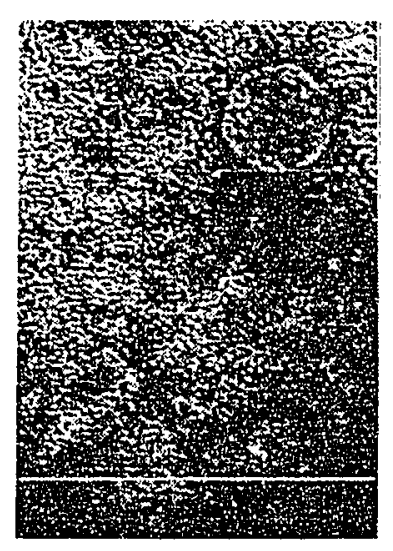

B.

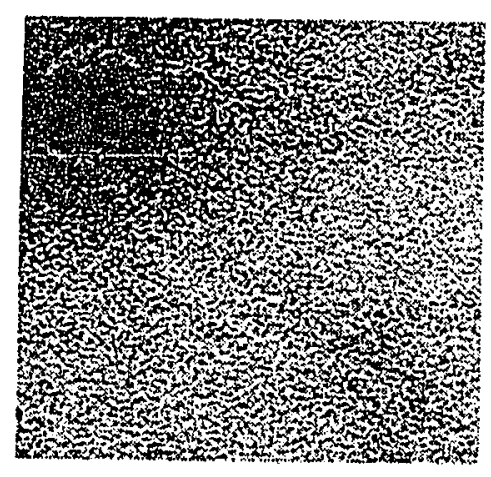

C.

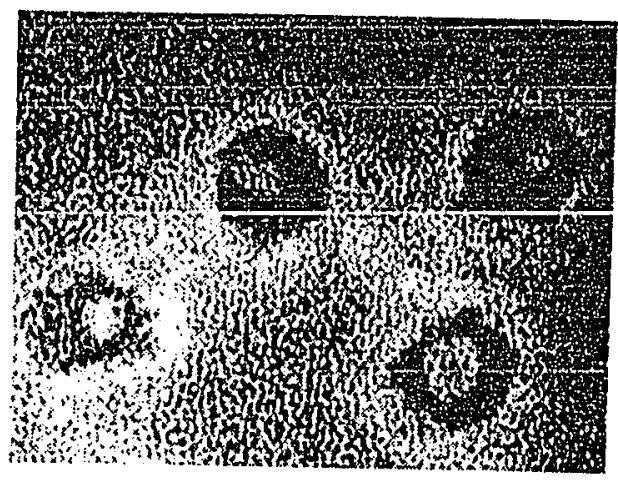

D.

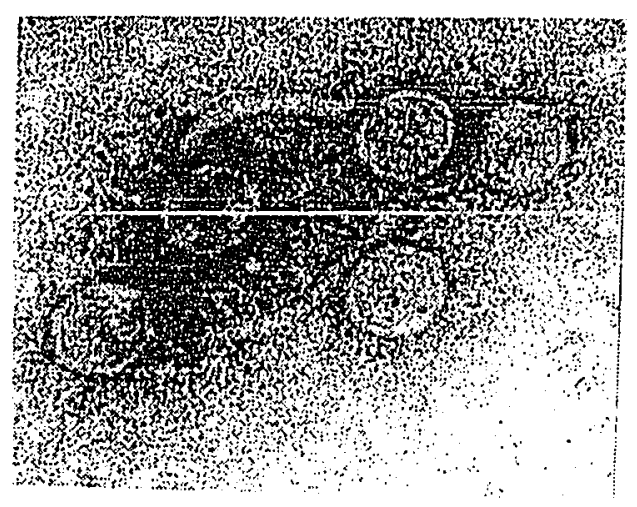

Figure 11. Electron micrographs of bacteriophages A.) Ø6-1, B.) $\emptyset 6-2$, C.) $\varnothing 6-5.1$ and D.) $\varnothing 12-1$. 
Table 11. Dimensions of bacteriophage particles. Values are the average of 25 particles.

\begin{tabular}{|c|c|c|}
\hline \multirow[t]{2}{*}{ Bacteriophage } & \multicolumn{2}{|c|}{ Dimensions } \\
\hline & Head diameter (nm) & Tail length (nm) \\
\hline $\begin{array}{l}\overline{\varnothing 6-1} \\
\varnothing 6-2 \\
\varnothing 6-5.1 \\
\varnothing 12-1\end{array}$ & $\begin{array}{l}21 \\
22 \\
22 \\
17\end{array}$ & $\begin{array}{l}42 \\
60 \\
N / A \\
56\end{array}$ \\
\hline
\end{tabular}

As shown in Figure 11, bacteriophages $\varnothing 6-1, \varnothing 6-2$ and $\varnothing 12-1$ have similar particle morphologies and dimensions. They are composed of a hexagonal head and a flexible and non-contractile tail. On the other hand, Ø6-5.1 had no visible tail and circular shaped head.

\section{Biochemical characterization of the bacteriophages}

In order to determine the sizes of the structural proteins of the bacteriophages, aliquots corresponding to $6 \times 10^{3} \mathrm{pfu}$ were subjected to SDS-PAGE (Figure 12). The apparent molecular weights of the structural proteins were calculated based on the relative mobilities of the standard proteins. These values are given in Table 12. 


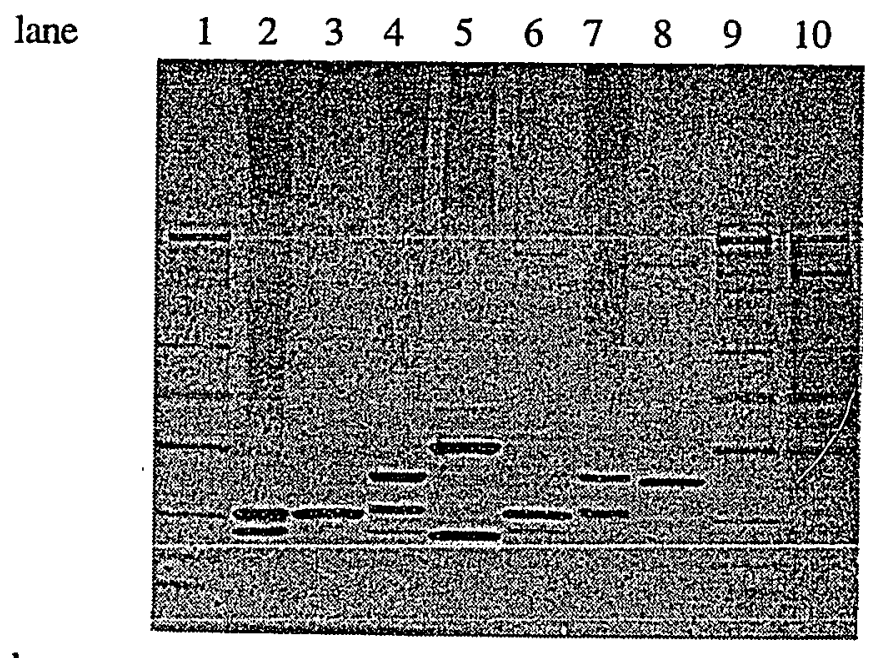

lane

$\begin{array}{llll}1 & \text { Bio-Rad broad mol. standard } & 6 & \emptyset 6-5.1(\mathrm{~b}) \\ 2 & \emptyset 6-1(\mathrm{a}) & 7 & \emptyset 12-1(\mathrm{a}) \\ 3 & \varnothing 6-1(\mathrm{~b}) & 8 & \emptyset 12-1(\mathrm{~b}) \\ 4 & \varnothing 6-2 & 9 & \text { Bio-Rad broad mol. wt. standard } \\ 5 & \varnothing 6-5.1(\mathrm{a}) & 10 & \text { Bio-Rad high mol. wt. standard }\end{array}$

Figure 12. SDS-PAGE gels of bacteriophage structural proteins. (a): designates propagation of phage by multiplicity of infection (plate method). (b): designates propagation of phage by induction of $B$. cereus 569 lysogen. The gel was silver stained. Biorad molecular weight marker bands:

$\begin{array}{ccc}\text { molecular weight (daltons) } & \text { high range } & \text { broad range } \\ 200,000 & \mathrm{X} & \mathrm{X} \\ 116,500 & \mathrm{X} & \mathrm{X} \\ 97,400 & \mathrm{X} & \mathrm{X} \\ 66,200 & \mathrm{X} & \mathrm{X} \\ 45,000 & \mathrm{X} & \mathrm{X} \\ 31,000 & & \mathrm{X} \\ 21,500 & & \mathrm{X} \\ 14,400 & & \mathrm{X} \\ 6,500 & & \mathrm{X}\end{array}$


Table 12. Apparent molecular weight of phage proteins.

\begin{tabular}{lll}
\hline Phage & \multicolumn{2}{c}{ Molecular weight (kDa) } \\
& Major proteins & Minor proteins \\
\hline$\varnothing 6-1(\mathrm{a})$ & 17,15 & \\
$\varnothing 6-1(\mathrm{~b})$ & 11,15 & 265,228 \\
$\varnothing 6-2$ & 21,18 & 15 \\
$\varnothing 6-5.1(\mathrm{a})$ & 26,15 & 34,28 \\
$\varnothing 6-5.1(\mathrm{~b})$ & 17,16 & $300,197,172$ \\
$\varnothing 12-1(\mathrm{a})$ & 22 & 17,17 \\
$\varnothing 12-1(\mathrm{~b})$ & 20 & $197,151,39,35$ \\
\hline
\end{tabular}

(a): bacteriophages obtained by infection of $B$. cereus 569 cells. (b): bacteriophages obtained from induced $B$. cereus 569 lysogens on plates denote phage propagated by the multiplicity of infection method.

\section{Analysis of bacteriophage DNA}

In order to compare the patterns of the various phage DNA restriction sites, DNA was extracted from crude bacteriophage stocks by two phenol extractions performed at $45^{\circ} \mathrm{C}$, followed by two chloroform extractions. The DNA was subsequently digested with a number of restriction endonucleases, and the digests were analyzed by agarose gel electrophoresis, the Sau3AI digest is shown in Figure 13. Results on the occurrence of restriction sites are presented in Table 13. 


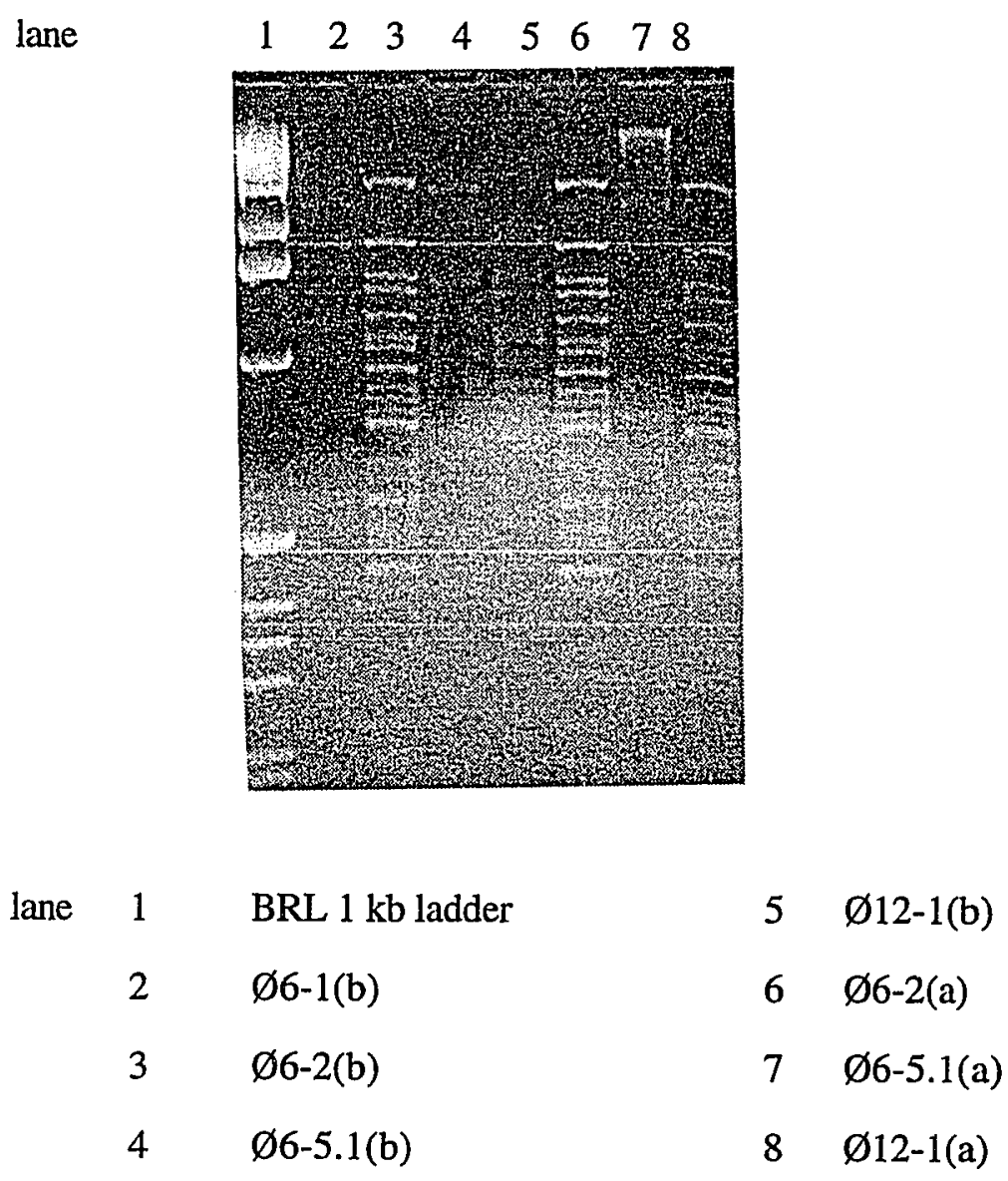

Figure 13. Agarose gel electrophoresis of bacteriophage DNA digested with Sau3AI restriction endonuclease. (a): bacteriophages obtained from induced B. cereus 569 lysogens. (b): bacteriophages obtained by infection of $B$. cereus 569 cells on plates. The BRL 1 kb ladder:

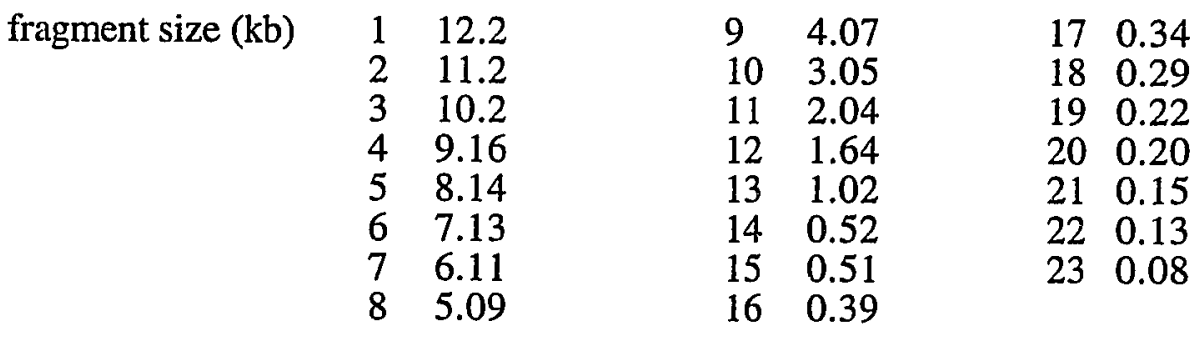


Table 13. Determination of the presence of restriction endonuclease sites on bacteriophage DNA.

\begin{tabular}{lcccccc}
\hline $\begin{array}{l}\text { Restriction } \\
\text { enzyme }\end{array}$ & $\varnothing 6-1$ & $\varnothing 6-2$ & $\varnothing 6-5.1(\mathrm{a})$ & $\varnothing 12-1(\mathrm{a})$ & $\emptyset 6-5.1(\mathrm{~b})$ & $\emptyset 12-1(\mathrm{~b})$ \\
\hline BamHI & + & - & + & + & + & - \\
EcoRI & + & + & - & + & + & + \\
HindIII & + & + & - & - & - & - \\
KpnI & - & + & + & + & - & - \\
NdeI & + & + & - & - & - & - \\
SacII & - & - & - & - & + & - \\
Sau3AI & + & + & + & + & + & + \\
XbaI & + & + & - & - & + & + \\
\hline
\end{tabular}

(a): bacteriophages obtained by infection of $B$. cereus 569 cells on plates. (b): bacteriophages obtained from induced $B$. cereus 569 lysogens. (+): presence of restriction sites. (-): absence of restriction sites.

Based on the restriction patterns observed, the bacteriophage genomes were digested with $E c o R I$, due to the limited number and size range of the restriction fragments obtained with this enzyme. The fragment sizes were carefully determined (Table 14), and the genome sizes (Table 14) were calculated by summing up the sizes of the EcoRI fragments. These ranged from 29,400 to $38,270 \mathrm{~kb}$. The DNA for phage $\varnothing 6-5.1$ degraded upon digestion with all restriction endonucleases and was therefore not included in Table 14. 
Table 14. Sizes of EcoRI restriction fragments and deduced total genome sizes of $B$. thuringiensis bacteriophages.

\begin{tabular}{cllll}
\hline$\varnothing 6-1$ & $\varnothing 6-2$ & $\begin{array}{c}\text { Bacteriophage } \\
\varnothing 6-5.1(\mathrm{~b})\end{array}$ & $\varnothing 12-1(\mathrm{a})$ & $\emptyset 12-1(\mathrm{~b})$ \\
\hline 9550 & 10,580 & 7930 & 10,580 & 6830 \\
6860 & 7620 & 5900 & 7620 & 4860 \\
5710 & 6500 & 5110 & 6500 & 4430 \\
3830 & 2840 & 3680 & 2840 & 3210 \\
2960 & 1860 & 3070 & 1860 & 2810 \\
2220 & & 2340 & & 2570 \\
2050 & & 2340 & & 2570 \\
1680 & & 2160 & & 2070 \\
1030 & & 1820 & & 7100 \\
890 & & 1170 & & 590 \\
630 & & 71000 & \\
590 & & 660 & \\
& & 380 & & \\
Total genome (bp) & 29,400 & 38,270 & 29,400 & 32,550 \\
38,000 & & & & \\
\hline
\end{tabular}

(a): bacteriophages obtained by infection of $B$. cereus 569 cells on plates. (b): bacteriophages obtained from induced $B$. cereus 569 lysogens.

\section{Restriction site mapping of bacteriophage $\emptyset 6-2$}

In order to obtain a partial genetic map of bacteriophage $\varnothing 6-2$, its genome was partially or completely digested with KpnI or HindIII, which cut only a limited number of times. The mapping was performed using the Flash Nonradioactive Gene Mapping Kit from Stratagene. The order of restriction fragments was determined based on the pattern obtained from the restriction site mapping kit results (Figure 14). 


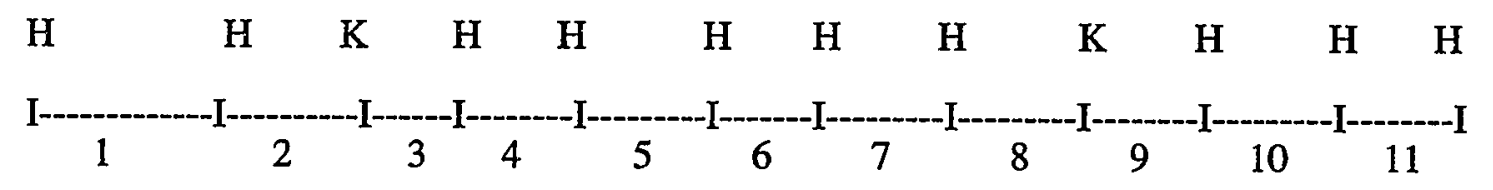

$\begin{array}{rllll}\text { fragment size }(\mathrm{kb}) & 1 & 12.0 & 7 & 2.1 \\ & 2 & 1.0 & 8 & 5.0 \\ & 3 & 0.68 & 9 & 1.0 \\ 4 & 0.22 & 10 & 0.6 \\ & 5 & 3.9 & 11 & 1.5 \\ 6 & 2.6 & & \end{array}$

Figure 14. Physical map of bacteriophage Ø6-2 for restriction endonucleases HindIII and KpnI. H: HindIII sites. K: KpnI sites. Fragments sizes are not drawn to scale.

\section{Genetic evidence of the similarity of $\emptyset 6-2$-like bacteriophages}

It was assumed earlier that several bacteriophages which did not plate on the $B$. cereus 569 strain lysogenic for $\emptyset 6-2$ must have shared similar genetic determinants. In order to verify this hypothesis, the restriction patterns of the genome of these bacteriophages were compared (Figure 15). Each bacteriophage DNA in the Ø6-2 family was digested with DraI and analyzed by agarose gel electrophoresis. 


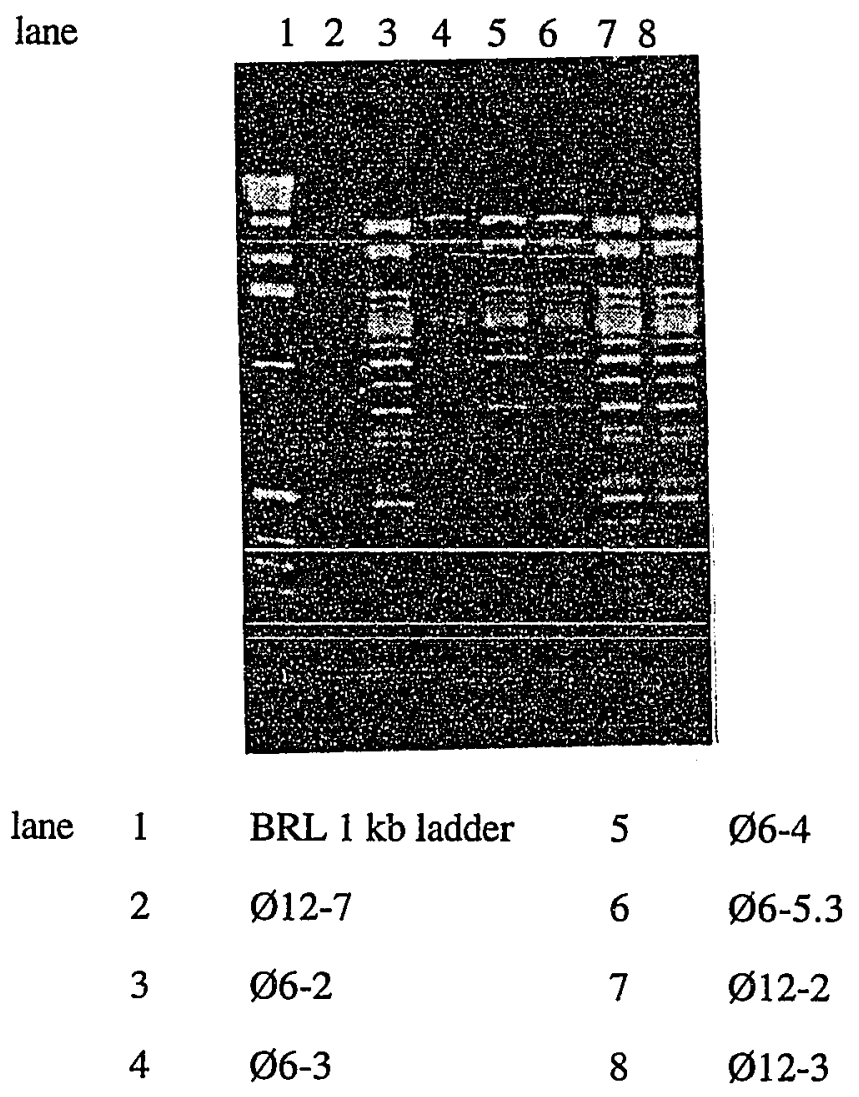

Figure 15. Restriction patterns of bacteriophages belonging to the $\emptyset 6-2$ family. Bacteriophage DNA was digested with DraI and the digests were analyzed by agarose gel electrophoresis. The amount of $\emptyset 12-7$ DNA was too low to be visualized on the gel. The BRL 1 kb ladder:

$\begin{array}{lllllll}\text { fragment size }(\mathrm{kb}) & 1 & 12.2 & 9 & 4.07 & 17 & 0.34 \\ & 2 & 11.2 & 10 & 3.05 & 18 & 0.29 \\ & 3 & 10.2 & 11 & 2.04 & 19 & 0.22 \\ & 4 & 9.16 & 12 & 1.64 & 20 & 0.20 \\ & 5 & 8.14 & 13 & 1.02 & 21 & 0.15 \\ & 6 & 7.13 & 14 & 0.52 & 22 & 0.13 \\ & 7 & 6.11 & 15 & 0.51 & 23 & 0.08 \\ & 8 & 5.09 & 16 & 0.39 & & \end{array}$


As shown in Figure 15, the identity of the restriction patterns supports the hypothesis that all of these bacteriophages belonged to the same family.

\section{Determination of the host range of the various bacteriophages}

The host ranges of the bacteriophages were determined in order to assess their potential distribution within the $B$. thuringiensis species. Each of the four bacteriophage was spotted on a lawn of indicator spores belonging to representative isolates of various subspecies of $B$. thuringiensis. Each has a unique host range (Table 15) when tested with strains of B. thuringiensis and B. cereus 569. 
Table 15. Host ranges of four bacteriophages.

\begin{tabular}{|c|c|c|c|c|c|}
\hline \multirow{2}{*}{$\begin{array}{l}\text { Bacterial strain } \\
\text { strain }\end{array}$} & \multirow{2}{*}{ subspecies } & \multicolumn{2}{|c|}{ Bacteriophage } & \multirow[b]{2}{*}{$\varnothing 6-5.1$} & \multirow[b]{2}{*}{$\varnothing 12-1$} \\
\hline & & $\varnothing 6-1$ & $\varnothing 6-2$ & & \\
\hline \multicolumn{6}{|c|}{ B. thuringiensis } \\
\hline HD73 & kurstaki & + & - & + & + \\
\hline $\mathrm{HD} 2$ & thuringiensis & - & - & - & - \\
\hline $\mathrm{HD} 229$ & aizawai & + & + & + & - \\
\hline HD1 & kurstaki & + & + & + & + \\
\hline SA3 (a) & israelensis & + & + & + & - \\
\hline $\mathrm{HD} 263$ & kurstaki & - & - & + & + \\
\hline SA10 (a) & tenebrionis & + & + & - & + \\
\hline Int $15-313$ (a) & kurstaki & + & - & + & $t$ \\
\hline B.t. & sotto & + & + & + & + \\
\hline $\begin{array}{l}\text { B.t. } \\
\text { HD137 }\end{array}$ & pakistani & - & - & + & $\begin{array}{l}+ \\
+\end{array}$ \\
\hline $\begin{array}{l}\text { HD137 } \\
\text { B.t. }\end{array}$ & $\begin{array}{l}\text { aizawai } \\
\text { kyushuensis }\end{array}$ & + & + & + & + \\
\hline Cutlass $^{\mathrm{TM}}$ (b) & кyusriuensts & - & - & - & - \\
\hline B.t. & ostriniae & & $=-$ & & - \\
\hline Foill $^{\mathrm{TM}}$ (b) & & - & - & - & + \\
\hline \multicolumn{6}{|l|}{ B. cereus } \\
\hline NRRL B-569 & & + & + & + & + \\
\hline
\end{tabular}

(a): Sandoz strains; (b): isolates obtained from registered products from Ecogen Inc. (Langhorne, PA); (+): lysis of test strain; (-): no lysis of test strain. Bacteriophages Ø65.1 and $\varnothing 12-1$ were obtained from plates containing infected lawns of $B$. cereus 569 .

\section{Determination of the efficiency of plating (eop) on various indicator strains}

The titer of the phages was determined by plating various concentrations of $\varnothing 6-1$ and $\varnothing 6-2$ lysate in $1 \times 10^{8}$ spores of each susceptible $B$. thuringiensis indicator strain. The titers obtained are presented in Table 16, and the plating efficiencies are calculated in Table 17. 
Table 16. Titers of plating bacteriophages $\emptyset 6-1, \varnothing 6-2, \varnothing 6-5.1$ and $\varnothing 12-1$ on various $B$. thuringiensis isolates and B. cereus 569 .

\begin{tabular}{|c|c|c|c|c|}
\hline \multirow{2}{*}{$\begin{array}{l}\text { Bacterial spores } \\
\text { strain subspecies }\end{array}$} & \multicolumn{3}{|c|}{ Titer (pfu/ml) } & \multirow[b]{2}{*}{$\varnothing 12-1$} \\
\hline & $\varnothing 6-1$ & $\varnothing 6-2$ & $\varnothing 6-5.1$ & \\
\hline HD73 kurstaki & - & - & $1.6 \times 10^{3}$ & - \\
\hline HD2 thuringiensis & - & - & $8 \times 10^{2}$ & - \\
\hline HD229 aizawai & - & - & $3 \times 10^{3}$ & $2.3 \times 10^{10}$ \\
\hline HD1 kurstaki & - & - & $1 \times 10^{2}$ & $2 \times 10^{5}$ \\
\hline SA3 (a) israelensis & - & $7.7 \times 108$ & $3 \times 10^{2}$ & $1.8 \times 10^{8}$ \\
\hline HD263 kurstaki & - & - & - & - \\
\hline SA10 (a) tenebrionis & - & $2.7 \times 10^{9}$ & $3.2 \times 10^{3}$ & - \\
\hline Int $15-313$ (a) kurstaki & - & - & $3.5 \times 10^{3}$ & - \\
\hline sotto & - & - & - & - \\
\hline pakistani & $5 \times 10^{3}$ & $1.6 \times 10^{9}$ & $1 \times 10^{2}$ & $1 \times 105$ \\
\hline HD137 aizawai & $6 \times 105$ & - & $5.6 \times 10^{3}$ & $3 \times 105$ \\
\hline B.t. kyushuensis & - & - & $7 \times 10^{3}$ & - \\
\hline Cutlass $^{\mathrm{TM}}$ (b) & - & - & $-\infty$ & - \\
\hline B.t. ostriniae & - & - & - & - \\
\hline Foil ${ }^{\mathrm{TM}}(\mathrm{b})$ & - & - & $1.5 \times 10^{4}$ & - \\
\hline \multicolumn{5}{|l|}{ B. cereus } \\
\hline NRRL B-569 & $7.5 \times 108$ & $3.2 \times 10^{11}$ & $6.9 \times 10^{4}$ & $1.2 \times 10^{12}$ \\
\hline
\end{tabular}

(a): Sandoz strains; (b): isolates obtained from registered products from Ecogen Inc. (Langhorne, PA) ; (-): phage did not produce a titer. 
Table 17. Efficiency of plating bacteriophages $\emptyset 6-1, \emptyset 6-2, \varnothing 6-5.1$ and $\emptyset 12-1$ on various B. thuringiensis isolates and B. cereus 569 .

\begin{tabular}{|c|c|c|c|c|c|}
\hline \multicolumn{2}{|c|}{ Bacterial spores } & \multicolumn{3}{|c|}{ Efficiency of plating } & \multirow[b]{2}{*}{$\varnothing 12-1$} \\
\hline & subspecies & $\varnothing 6-1$ & $\varnothing 6-2$ & $\varnothing 6-5.1$ & \\
\hline HD73 & kurstaki & - & - & $2.3 \times 10^{-2}$ & - \\
\hline $\mathrm{HD} 2$ & thuringiensis & - & - & $1.2 \times 10^{-2}$ & - \\
\hline HD229 & aizawai & - & - & $4.3 \times 10^{-2}$ & $1.9 \times 10-2$ \\
\hline HD1 & kurstaki & - & - & $1.4 \times 10^{-3}$ & $1.7 \times 10-7$ \\
\hline $\mathrm{SA} 3$ (a) & israelensis & - & $2.4 \times 10^{-3}$ & $4.3 \times 10^{-3}$ & $1.5 \times 10^{-4}$ \\
\hline $\mathrm{HD} 263$ & kurstaki & - & - & . & \\
\hline SA10 (a) & tenebrionis & - & $8.4 \times 10^{-3}$ & $4.6 \times 10^{-2}$ & - \\
\hline Int $15-31$ & 3 (a) kurstaki & - & - & $5.1 \times 10^{-2}$ & - \\
\hline B.t. & sotto & - & - & - & \\
\hline B.t. & pakistani & $6.7 \times 10^{-6}$ & $5 \times 10-3$ & $1.4 \times 10^{-3}$ & $8.3 \times 10^{-8} 8$ \\
\hline HD137 & aizawai & $8 \times 10^{-4}$ & - & $8.1 \times 10^{-2}$ & $2.5 \times 10^{-7}$ \\
\hline B.t. & kyushuensis & - & - & $1.0 \times 10^{-1}$ & . \\
\hline $\begin{array}{l}\text { Cutlass }^{\mathrm{TN}} \\
\text { B.t. }\end{array}$ & $\begin{array}{l}\text { (b) } \\
\text { ostrinize }\end{array}$ & - & - & - & - \\
\hline $\begin{array}{l}\text { Foil } \\
\text { B. cereus }\end{array}$ & & - & - & $2.2 \times 10-1$ & - \\
\hline NRRL B & -569 & 1 & 1 & 1 & 1 \\
\hline
\end{tabular}

(a): Sandoz strains; (b): isolates obtained from registered products from Ecogen Inc. (Langhorne, PA); (-): phage did not produce a titer.

The results presented above show that the efficiency of plating on the $B$. thuringiensis hosts was 5- to $5 \times 107$ - fold lower than the efficiency of plating on $B$. cereus 569 , which was used to propagate the phages.

In order to determine whether the plating efficiency was influenced by the origin of the bacteriophage (i. e. the strain on which the phage was propagated) bacteriophage Ø61 and Ø6-2 were grown on various $B$. thuringiensis strains as follows. Phages from 
plaques isolated from $B$. cereus 569 were mixed with various $B$. thuringiensis indicators and plated. From these plates, phages were again isolated from plaques and repurified twice on the same indicator strain. Finally, an isolated plaque was resuspended and dilutions were plated on the host strain used to propagate the phage as well as on the indicator B. cereus 569. Results from this experiment are shown in Table 18.

Table 18. Influence of the host strain on the efficiency of plating of bacteriophages $\varnothing 6-1$ and Ø6-2.

\begin{tabular}{llll} 
Bacteriophage & Purification bacterial strain & \multicolumn{2}{c}{ Titers on } \\
& origin (a) & origin strain & B.c. 569 \\
\hline$\varnothing 6-1$ & B.t. HD137 & $1.9 \times 10^{7}$ & $2.1 \times 10^{7}$ \\
$\varnothing 6-1$ & B.t. pakistani & $3.9 \times 10^{7}$ & $4 \times 10^{3}$ \\
$\varnothing 6-2$ & B.t. SA3 & $1.4 \times 10^{2}$ & $2 \times 10^{4}$ \\
$\varnothing 6-2$ & B.t. pakistani & $1.1 \times 10^{7}$ & $2.7 \times 10^{4}$ \\
\hline
\end{tabular}

(a): strain on which the phages were propagated. B. t.: B. thuringiensis . B. c. : B. cereus 569.

With the exception of the phages propagated on strain HD137, which plated with an equal efficiency on both the origin strain and B. cereus 569, all other phages plated with $10^{2}$ to $10^{4}$ lower efficiency on $B$. cereus 569 than on the strain from which they originated. 


\section{Detection of the bacteriophage $\emptyset 6-2$ by polymerase chain reaction}

Polymerase chain reaction (PCR) was used as an alternative to physiological methods for the detection of bacteriophage within B. thuringiensis. Two sets of oligonucleotide primers were designed for the detection of phage Ø6-2, based on the sequence data obtained (not shown) in the course of this study (Table 19). The two sets of primers were complimentary to two different fragments of the genome of the bacteriophage Ø6-2. LA19 and LA20 produced a fragment of $126 \mathrm{bp}$, while LA21 and LA22 produced a product of $800 \mathrm{bp}$.

Table 19. Oligonucleotide primers for the detection of $\varnothing 6-2$.

\begin{tabular}{lll}
\hline Primer & Sequence & G+C Tm Amplicon size \\
designation & (a) (b) (c)
\end{tabular}

$\begin{array}{llllll}\text { LA19 } & \text { ATCTTTCACAACAACCTTTAGGCTATCCC } & 41 & 60.1 & 126 \mathrm{bp} \\ \text { LA20 } & \text { GTAAGTTTGGATGTGTTAGATGAAGCAGCC } & 43 & 61.8 & \\ \text { LA21 } & \text { GAGCAAGCAATTGAAGCGTAGGGA } & 50 & 60.4 & 800 \mathrm{bp} \\ \text { LA22 } & \text { CCAACCTCAATTAACTTTTGAGATACGCCT } & 40 & 62.3\end{array}$

(a): Percent G+C. (b): Melting temperature. (c): Calculated from the sequence data.

PCR amplifications were run using these primer sets and crude DNA isolated from various strains of $B$. thuringiensis in order to determine the presence of phage $\varnothing 6-2$ (Table 20). 
Table 20. Amplification of fragments of bacteriophage DNA by PCR.

\begin{tabular}{|c|c|c|c|c|}
\hline Source of DNA & & Subspecies & & ation (a) \\
\hline & & & & $\mathrm{LA} 21 / 22$ \\
\hline Bacteriophage & $\varnothing 6-1$ & & - & - \\
\hline & $\varnothing 6-2$ & & + & + \\
\hline & $\varnothing 6-5.1$ & & - & - \\
\hline & $\varnothing 12-1$ & & + & + \\
\hline B.cereus & $569:: 6-1$ & & - & - \\
\hline & $569:: 6-2$ & & + & + \\
\hline & 569 & & - & - \\
\hline B. thuringiensis & $I N T \quad 15-313$ & & - & - \\
\hline & HD1 & kurstaki & - & - \\
\hline & HD12 & morrisoni & - & - \\
\hline & HD52 & aizawai & + & + \\
\hline & HD73 & kurstaki & - & - \\
\hline & HD112 & aizawai & + & + \\
\hline & HD125 & tolworthi & + & + \\
\hline & $\mathrm{HD} 127$ & aizawai & + & + \\
\hline & HD131 & aizawai & + & + \\
\hline & HD132 & aizawai & + & + \\
\hline & HD133 & aizawai & + & + \\
\hline & HD134 & aizawai & + & + \\
\hline & HD136 & kenyae & - & - \\
\hline & HD137 & aizawai & + & + \\
\hline & HD147 & darmstadiensis & - & - \\
\hline & HD198 & entomecidus & - & - \\
\hline & HD203 & kurstaki & - & - \\
\hline & $\mathrm{HD} 207$ & galleriae & - & - \\
\hline & $\mathrm{HD} 228$ & aizawai & + & + \\
\hline & HD229 & aizawai & + & - \\
\hline & HD232 & galleriae & - & - \\
\hline & HD234 & galleriae & + & + \\
\hline & HD245 & kurstaki & - & - \\
\hline & HD248 & aizawai & + & + \\
\hline & HD263 & kurstaki & + & + \\
\hline & $\mathrm{HD} 272$ & aizawai & + & + \\
\hline & HD275 & not identified & - & + \\
\hline & HD282 & aizawai & + & + \\
\hline & HD283 & aizawai & + & + \\
\hline & $\mathrm{HD} 301$ & tolworthi & + & + \\
\hline & HD567 & israelensis & - & - \\
\hline
\end{tabular}

$(+)$ : presence of a band of correct size; (-): absence of a band of correct size. 
In most of the cases, the reactions were either positive or negative for both sets of primers, but in two cases (HD229 and HD275), only one of the reactions gave a PCR product of the correct size. It is noteworthy that only one of the subspecies kurstaki isolates (HD263) was positive. 


\section{Discussion}

In this study, bacteriophages isolated from two strains of $B$. thuringiensis subspecies kurstaki were characterized at the physiological, biochemical and genetic levels. This subspecies was selected because it is the most widely used in large-scale industrial production of biological insecticides. The two strains used in the investigation, HD119 and HD942, were chosen because of their propensity to lyse on nutrient plates in areas of high cell density. This phenomenon was even more apparent on plates inoculated with recombinant derivatives of these two strains containing, either plasmid vectors such as pSB909.5 harboring additional cry genes (Gamel and Piot, 1992), or derivatives containing cry genes integrated into the chromosome (Sue Kalman, personal communication). This has important implications for the prospect of future development of transgenic derivatives of $B$. thuringiensis strains, since lysis of the bacterial culture during fermentation can be a major source of yield loss.

A number of bacteriophages, distinguishable mainly by the morphology of their plaques, were isolated. These bacteriophages belonged to either of the two main types of phages, namely virulent phages, which lyse the bacteria they infect after an intracellular round of multiplication, and the temperate phages, which have the alternative of either lysing the infected bacteria in the same way as the virulent phages, or establishing a symbiotic relationship with the host cell. Bacteria that carry phage in this way are known as lysogenic, and the carried phage is known as a prophage. The decision toward a lytic or lysogenic response is largely determined by the physiological state of the bacteria and can be modified by environmental conditions (Calendar, 1988). Plaques produced by virulent

phage are nearly always clear, since all the infected bacteria lyse, while infection by 
temperate phage yield turbid plaques due to the growth, within the plaque, of the lysogenic bacteria which have become immune to superinfection. Most of the bacteriophages isolated were temperate (Ø6-1, Ø6-2, Ø6-3, Ø6-4, Ø6-5.3, Ø12-2, Ø12-3 and Ø12-7) while only two were virulent (Ø6-5.1 and Ø12-1).

All of the temperate bacteriophages could be separated in two classes by determining their ability to produce a clearing when spotted on lysogenic derivatives of $B$. cereus 569 containing each of the other phages. A bacteriophage which shares identical regulatory functions with a prophage, cannot superinfect a strain lysogenic for that homologous prophage. Thus, the inability of bacteriophages Ø6-2, Ø6-3, Ø6-4, Ø6-5.3, $\varnothing 12-2, \varnothing 12-3$ and $\emptyset 12-7$ to produce a clearing upon spotting phage stocks on a lawn of B. cereus 569 lysogenic for each of the other bacteriophages allowed them to be grouped in a single immunity class. This classification was further verified at the genetic level by isolating the genomic DNA of all the different bacteriophages in this class and digesting these DNAs with restriction endonucleases. The restriction patterns of all of the various phage genomes were identical, indicating a complete homology within the limits of resolution of this method, and thus showing that the absence of plating capability was indeed due to immunity to superinfection, even though the morphologies of the individual plaques were quite different.

Although the physiological methods used detect the ability of the phages to infect various $B$. thuringiensis strains (spotting, plating efficiency determination) were generally consistent, there were a few instances where equivocal resuits were obtained. For example when bacteriophages $\emptyset 6-1$ was spotted on lawns of $B$. thuringiensis HD73, HD229 or HD1, a spot of clearing could be observed. Yet, when dilutions of Ø6-1 were plated on the same $B$. thuringiensis strains, no plaques could be detected, although the range of 
dilutions of the bacteriophage stocks was broad enough to exclude the possibility of missing the phage concentration allowing detection of the phages. A possible explanation for these results could be the phenomenon known as lysis from without. In the spot test a highly concentrated stock of the bacteriophage is added to a small area of the plate containing approximately $1 \times 10^{6}$ spores, so that the multiplicity of infection is greater than 1. In such a case, a large number of phages are able to lyse the cell at the time of adsorption, although the cells may be in fact immune to superinfection, as shown by the absence of plating efficiency. The opposite result was also observed. When bacteriophage Ø6-1 was plated on B. thuringiensis subspecies pakistani, no clearly defined spot was visible, yet when dilutions of the phage stock were plated, small isolated plaques could be seen. This latter result pointed to the limitation of these physiological tests and a more reliable methodology was sought. A likely candidate is the application of PCR analysis to the detection of bacteriophage genetic determinants in the bacterial genome. In order to develop this tool, the nucleotide sequence of several fragments of bacteriophage Ø6-2 was determined, and oligonucleotide primers were derived from the sequence information.

A comparison of the results obtained with PCR detection with those of the spot tests and efficiency of plating experiments showed that the level of sensitivity of the physiological methods were insufficient. The presence of a spot in the spot test was originally attributed to the absence of the corresponding prophage. By contrast, the inability of the bacteriophage to form plaques when titered on the various indicator strains was interpreted as the presence of the corresponding prophage. These observations taken alone did not allow unequivocally ascertainment of the presence or the absence of the prophages. In particular, $B$. thuringiensis subspecies kurstaki $\mathrm{HD} 1$, and $B$. thuringiensis subspecies aizawai HD137 and HD229 gave ambiguous results, since they showed a 
clearing in the spot test yet were unable to allow plaque formation. As mentioned above, the opposite case was observed with $B$. thuringiensis subspecies pakistani, which did not show a spot but did allow plaquing of $\varnothing 6-2$.

The implementation of PCR analysis helped to clarify these results. For strains HD137, HD263 and HD229, the absence of plaquing capability correlated with positive PCR reactions, indicating the presence of $\varnothing 6-2$. The fact that only one of the primer sets gave positive results with HD229 could be due to the larger size of the PCR product and sub-optimal amplification conditions or, alternatively, to some genetic rearrangements taking place within the boundaries defined by the oligonucleotide primers. For strains HD73 and INT-15-313, the absence of spotting and plaquing capability together with the negative PCR results pointed to the resistance of these strains, possibly because of the absence of specific receptors for $\varnothing 6-2$ on the bacterial surface. Some ambiguity remained in the case of HD1, for which no clear interpretation of the results could be inferred; the strain was susceptible to the phage at high m. o. i., yet was unable to support plaquing and was PCR-negative.

When bacteriophage stocks propagated on $B$. cereus 569 were plated on various $B$. thuringiensis strains, two types of responses were observed. In many cases, no plaques could be seen, pointing to either resistance or immunity to the phages. In the other cases, the titers obtained on $B$. thuringiensis were much lower than those seen on $B$. cereus. In order to determine whether theses differences in plating efficiencies were dependent on the origin of the bacteriophages. Two of the phages were propagated on several $B$. thuringiensis strains, and the titers of the stocks were determined on $B$. cereus as well as on the strain used for propagation. The titers of these phage stocks were lower on $B$. cereus than on $B$. thuringiensis, with the notable exception of Ø6-1 propagated on 
strain HD137. It thus seems that among the four strains examined, three may have one or more modification/restriction systems that are distinct from those of $B$. cereus. It can be hypothesized that HD137 contains all of the restriction/modification systems of B. cereus, since phages propagated on HD137 must contain at least one supplemental restriction/modification system to account for the decrease in plating efficiency of phages propagated on B. cereus 569.

Transmission electron microscopy was used to visualize the phage particles. The general morphologies of bacteriophages $\varnothing 6-1, \varnothing 6-2$ and $\varnothing 12-1$ were similar. They had a hexagonal head and noncontractile tail. On the other hand, bacteriophage $\varnothing 6-5.1$ had a circular head and no tail could be detected. The dimensions of the bacteriophages were determined by measuring electron micrographs. Surprisingly, in spite of their extensive homology at the genetic level, bacteriophages $\varnothing 6-2$ and $\varnothing 12-1$ displayed significant morphological differences, in the size of the head (22 nm for Ø6-2 and $17 \mathrm{~nm}$ for $\varnothing 12-1)$. This is reminiscent of the results of Kochkina et al. (1978) and Kochkina (1986a), who made similar observations with a temperate phage of $B$. thuringiensis subspecies galleriae and its virulent mutant.

A puzzling result was the difference observed between the two virulent phages $\varnothing 6-5.1$ and $\varnothing 12-1$ and their respective temperate counterparts that were isolated at a later date. These phages show considerable differences in both their protein composition, and their DNA sequences, as judged by the differences in their restriction patterns. Clearly, this phenomenon deserves further investigation.

A partial restriction map of bacteriophage $\varnothing 6-2$ was constructed with the SuperCos Mapping Kit (Stratagene). This cosmid vector was chosen because of its capability for cloning $30-42 \mathrm{~kb}$ of DNA, which was well suited to the size of the complete 
bacteriophage genome. However, the vast majority of the clones obtained contained inserts that were $10-12 \mathrm{~kb}$ in size, which precluded any possibility of mapping the complete genome using this strategy. Nevertheless, by a combination of partial digests and overlap analysis, it was possible to order the restriction fragments and construct the complete restriction map of Ø6-2 for the restriction endonucleases HindIII and KpnI. 


\section{Literature Cited}

Ackermann, H.-W. 1974. The classification of bacteriophages of Bacillus at Clostridium. Pathol. Biol., 22: 909-917.

Ackermann, H.-W., R. R. Azizbekyan, H. P. Emadi Konjin, M.-M. Lecadet. 1994. New Bacillus bacteriophage species. Arch. Virol.,135: 333-344.

Auffray, Y. and P. Boutibonnes. 1985. Discriminated induction of prophage and bacteriocin in Bacillus thuringiensis strains by genotoxic agents. IRCS Med. Sci., 13: 679680.

Azizbekyan, R.R., T. A. Smirnova, I. B. Minenkova, B. A. Rebentish. 1980. Lysogeny in Bacillus thuringiensis. Microbiology (engl. transl. Mikrobiologiya), 49(6): 961-968.

Besaeva, S.G., A. A. Mikhailov, T. M. Petrova, A. I. Tur, E. V. Bystrova. 1987. Spontaneous induction of bacteriophage in Bacillus thuringiensis. Microbiology (engl. transl. Mikrobiologiya), 56(5): 816-818.

Calendar, R. 1988. The Bacteriophages. Plenum Press, N. Y.

Chomczynski, P. 1992. One hour alkaline capillary transfer for blotting DNA and RNA. Anal. Biochem., 201: 133-139.

Colasito, D.J., and, M. H. Rogoff. 1969. Characterization of temperate bacteriophages of Bacillus thuringiensis. J. Gen.Virol., 5: 275-281.

Franki, R. I. B., C. M. Fauquet, D. L. Knudson, F. Brown (eds). 1991. Classification and nomenclature of viruses. Fifth Report of the International Committee of Viruses. Springer, Wein New York. Arch. Virol. [Suppl.].

Gamel, P. H. and J.-C. Piot. 1992. Characterization and properties of a novel plasmid vector for Bacillus thuringiensis displaying compatibility with host plasmids. Gene, 120: 17-26.

Heierson, A., I. Sidén, A. Kivaisai, H. G. Boman. 1986. Bacteriophage-resistent mutants of Bacillus thuringiensis with decreased virulence in pupae of Hyalophora cecropia. J. Bacteriol., 167(1): 18-24.

Inal, J. R. M., V. Karunakaran, H. D. Burges. 1990. Isolation and propagation of phages naturally associated with the aizawai variety of Bacillus thuringiensis. J. Appl. Bacteriol., 68: 17-21.

Inal, J. R. M., V. Karunakaran, H. D. Burges. 1992. Generalized transduction in Bacillus thuringiensis var. aizawai. J. Appl. Bacteriol., 72: 87-90. 
Jarvis, A. W., L. J. Collins, H.-W. Ackermann. 1993. A study of five bacteriophages of the Myoviridae family which replicate on different gram-positive bacteria. Arch. Virol., 133: 75-84.

Jones, D.R., V. Karunakaran, H. D. Burges. 1983. Phages naturally associated with the aizawai variety of insect pathogen Bacillus thuringiensis and their relevance to strain identification. J. Appl. Bacteriol., 54: 373-377.

Kanda, K., and K. Aizawa. 1988. Selective induction of two temperate phages in Bacillus thuringiensis strain AF101. Agric. Biol. Chem., 53(10): 2819-2820.

Kochkina, Z.M. 1986a. Comparative study of certain physiochemical and biological properties phage of Bacillus thuringiensis. Microbiology (engl. transl. Mikrobiologiya), 55(1): 127-130.

Kochkina, Z.M. 1986b. Structural features of Bacillus thuringiensis. Microbiology (engl. transl. Mikrobiologiya), 55(6): 1005-1008.

Kochkina, Z.M., T. P. Blokhina, Ya. L. Rautenshtein. 1978. Polylysogeny of cultures of Bacillus thuringiensis var. galleriae. Microbiology (engl. transl. Mikrobiologiya), 46(4): $730-736$.

Koroleva, Yu. V., T. M. Grigor'eva, R. R. Azizbekyan. 1992. Isolation and characteristics of phage-resistant mutants of Bacillus thuringiensis var. thuringiensis. Sov. Biotechnol., 2: 3-5.

Koroleva, Yu. V., T. M. Grigor'eva, T. A. Smirnova, R. R. Azizbekyan. 1990. Bacterial modification of Bacillus thuringiensis phages. Sov. Biotechnol., 6: 12-15.

Kretz, P. L., C. H. Reid, A. Greener, J. M. Short. 1989. Effect of lambda packaging extract $m c r$ restriction activity on DNA cloning. Nucleic Acids Res., 17: 5409.

Laemmli, U. K. 1970. Cleavage of structural proteins during assembly of the head of bacteriophage T4. Nature, 227: 680-685.

Landén, R., A. Heierson, H. G. Boman. 1981. A phage for generalized transduction in Bacillus thuringiensis and mapping of four genes for antibiotic resistance. J. Gen.

Microbiol., 123: 49-59.

Lecadet, M.-M., M.-O. Blondel, J. Ribier. 1980. Generalized transduction in Bacillus thuringiensis var. berlinger 1715 using bacteriophage CP-54Ber. J. Gen. Microbiol., 121: 203-212.

Maniatis, T., E. F. Fritsch, J. Sambrock. 1985. Molecular Cloning a Laboratory Manual. Cold Springs Harbor Laboratory publication, N. Y. 11th issue.

Manuel, C. and D. Karamata. 1984. Characterization of proteins of induced mitomycin C 
treatment of Bacillus subtilis. J. Virol., 49(3): 806-812.

Perlak, F. J., C. L. Mendelsohn, C. B. Thorne. 1979. Converting bacteriophage for sporulation and crystal formation in Bacillus thuringiensis. J. Bacteriol., 140: 699-705.

Rautenshtein, Ya. I., L. N. Moskalenko, I. A. Bespalova, A. S. Tikhonenko. 1975. Ultrastructure of bacteriophage specific to Bacillus thuringiensis var. galleriae.

Microbiology (engl. transl. Mikrobiologiya), 45(4): 690-694.

Rautenshtein, Ya. I., N. Ya. Solov'eva, G. E. Kurkovskaya, T. P. Blokhina, L. N. Moskalenko, A. D. Filatova. 1970. Characterization of lysogeny and of temperate phages of strains of spore-bearing, crystal-forming, entomopathogenic microorganisms isolated from various sources. Microbiology, 40: 468-475.

Reynolds, R. B., A. Reddy, C. B. Thorne. 1988. Five unique temperate phages from a polylysogenic strain of Bacillus thuringiensis subsp. aizawai. J. Gen. Microbiol., 134: $1577-1585$.

Ruhfel, R. E., N. J. Robillard, C. B. Thorne. 1984. Interspecies transduction of plasmids among Bacillus anthracis, $B$. cereus and B. thuringiensis. J. Bacteriol., 157(3): 708-711.

Smirnova, T. A., E. M. Netyksa, I. B. Minenkova, V. B. Smirnov, R. R. Azizbekyan. 1979. Electron-microscopic study of the interactions between phages and Bacillus thuringiensis cells. Microbiology (engl. transl. Mikrobiologiya), 48(5): 880-886.

Thorne, C. B. 1978. Transduction in Bacillus thuringiensis. Appl. Environ. Microbiol., 35(6): 1109-1115.

Yaphe, W. 1957. The use of agarase from Pseudomonas atlantica in the identification of agar in marine algae (Rhodophyceae). Can. J. Microbiol., 3: 987-993.

Zamola, B., A. Saric, G. Karminski-Zamola, C. Sidor. 1983. Aeration-provoked formation of bacteriophages in cultures of Bacillus thuringiensis var. thuringiensis (Berlinger). Eur. J. Appl. Microbiol. Biotechnol., 17: 103-106. 